\title{
8. CARIBBEAN VOLCANISM, CRETACEOUS/TERTIARY IMPACT, AND OCEAN-CLIMATE HISTORY: SYNTHESIS OF LEG $165^{1}$
}

\author{
Shipboard Scientific Party ${ }^{2}$
}

\section{INTRODUCTION}

From December 1970 to February 1971, scientists on Leg 15 of the Deep Sea Drilling Project (DSDP) drilled nine sites in the Caribbean Sea (Edgar, Saunders, et al., 1973). Their drilling results were fundamental to the discovery that the Caribbean is underlain by oceanic crust of anomalous character, and led to the identification of the basin-wide B" seismic reflector as the upper surface of a volcanic oceanic basalt plateau (Ewing et al., 1968). Earlier, DSDP Leg 4 drilling had led to the discovery that the $\mathrm{A}^{\prime \prime}$ seismic reflector in the overlying sediments is caused by a persistent horizon of early Eocene cherts (Bader, Gerard, et al., 1970).

Twenty-five years later the Ocean Drilling Program (ODP) has returned, with the drilling of $5952 \mathrm{~m}$ at five sites across the Caribbean during Leg 165 (Figs. 1,2). The drilling has yielded a wealth of new results, including the discovery of a spectacular record of explosive volcanism from Central America and the Caribbean region. The record of Eocene and Miocene explosive volcanism recovered at four of the sites is unmatched in its magnitude and chronostratigraphic resolution, and includes the first documentation of arc volcanism along the Cayman Ridge. The age, physical characteristics, and geochemistry of the basalts cored at Site 1001 bear importantly on the tectonic history of the Caribbean Plate as a Large Igneous Province (LIP). A double-cored mid-Campanian to lower Eocene section at Site 1001 includes Cretaceous/Tertiary $(\mathrm{K} / \mathrm{T})$ boundary impact ejecta deposits and a unique deep-sea record of a transient global warming event ("late Paleocene thermal maximum"). The recovery of the K/T boundary in three holes of the Caribbean provides new insights into the nature of the bolide impact, dispersal mechanisms of ejecta, and depositional processes in the deep sea. The spatial distribution of a middle/late Miocene minimum in carbonate accumulation ("carbonate crash") was extended from a regional Pacific dissolution event (or series of events) to an interbasinal tropical event, probably related to changes in oceanic circulation. Continuous Neogene sequences also reveal the history of intermediate- and deep-water mass history and circulation across the basin, and document the impact of the closure of the Central American Seaway on the evolution of the global ocean conveyor-belt circulation. Site 1002 in the anoxic Cariaco Basin contains a laminated sedimentary sequence representing a unique tropical counterpart to high-latitude ice cores for studies of rapid climate changes in the latest Quaternary. The detailed results of drilling at each site are given in the site chapters of this volume and the principal highlights are given below.

\section{RECORD OF CARIBBEAN PELAGIC SEDIMENTATION}

\section{Paleogene and Late Cretaceous}

Carbonate mass accumulation rates (MARs) were stable throughout the upper Campanian-Maastrichtian interval at Site 1001, and

'Sigurdsson, H., Leckie, R.M., Acton, G.D., et al., 1997. Proc. ODP, Init. Repts., 165: College Station, TX (Ocean Drilling Program).

${ }^{2}$ Shipboard Scientific Party is given in the list preceding the Table of Contents. where in the deep sea and may be attributed to depressed carbonate productivity in the aftermath of the $\mathrm{K} / \mathrm{T}$ boundary extinction event (e.g., Zachos and Arthur, 1986; D'Hondt et al., in press). Minimum values persist through much of early Paleocene time with average sedimentation rates less than $5 \mathrm{~m} / \mathrm{m} . \mathrm{y}$.

Carbonate MARs rebound through the upper Paleocene-lower Eocene at Sites 999 and 1001 . These sites were either at comparable depths (>3000 m), or Site 1001 was somewhat deeper during the late Paleocene-early Eocene. The differences in carbonate MARs between the two sites are probably attributable, therefore, to greater rates of carbonate productivity at Site 1001, rather than to greater dissolution at Site 999.

A pair of major unconformities account for the loss of much of the lower Eocene-middle Miocene record at Site 1001. The middle Eocene at Sites 998 and 999 is characterized by rising, then falling rates of carbonate accumulation. Sedimentation rates decrease sharply in the upper middle Eocene at Site 999.

Carbonate MARs are generally stable through the upper Eocene and Oligocene of Sites 998 and 999 . However, the two sites have sharply contrasting patterns of sediment accumulation across the Oligocene/Miocene boundary. At Site 998 on the Cayman Rise, the late Eocene-Oligocene carbonate MARs are higher than at Site 999, but then decrease sharply in early Miocene time. In contrast, at Site 999 the carbonate MARs increase dramatically across the Oligocene/ Miocene boundary, before beginning a steady decline through the middle Miocene (Fig. 3). Tectonic changes in the Caribbean near the time of the Oligocene/Miocene boundary may be responsible for a major reorganization of carbonate productivity between the northern and southwestern Caribbean. For example, partial foundering of a carbonate megabank along the northern Nicaraguan Rise (NNR), as suggested by the presence of early Miocene corals dredged from the area of Pedro Channel (Droxler et al., 1992), may have significantly changed surface- and intermediate-water circulation. In addition, foundering of the Aves Ridge in the eastern Caribbean may have also contributed to a major reorganization of circulation through the Caribbean (Droxler and Burke, 1995). Enhanced carbonate productivity along a zone of divergence between the west-flowing North Equatorial Current and the east-flowing North Equatorial Countercurrent in the southwestern Caribbean may be responsible for the increased carbonate MARs at Site 999 during early Miocene time. An open Central American Seaway at that time may have allowed the interbasinal flow of surface waters and a pattern of productivity similar to that of the tropical North Pacific today.

Several thick volcaniclastic turbidites and andesitic ash layers are responsible for the significant increase in noncarbonate MARs in mid-Campanian strata overlying basaltic basement at Site 1001, whereas pulses of heightened noncarbonate MARs in the Paleocene of Sites 999 and 1001 record the presence of discrete volcanic ash layers and dispersed ash within the sediments. Similarly, noncarbonate MARs are distinctly high in the lower and middle Eocene at Sites 998,999 , and 1001, particularly in the interval near the lower/middle Eocene boundary (52-48 Ma). This corresponds to a large flux of dispersed ash and discrete volcanic ash layers, and in the case of Site 998, ash turbidites, associated with magmatic activity along the Cayman arc (see below). 
Figure 1. Location map of Leg 165 sites (squares). Topography is from the etopo5 data set in the GMT software package (Wessel and Smith, 1991).
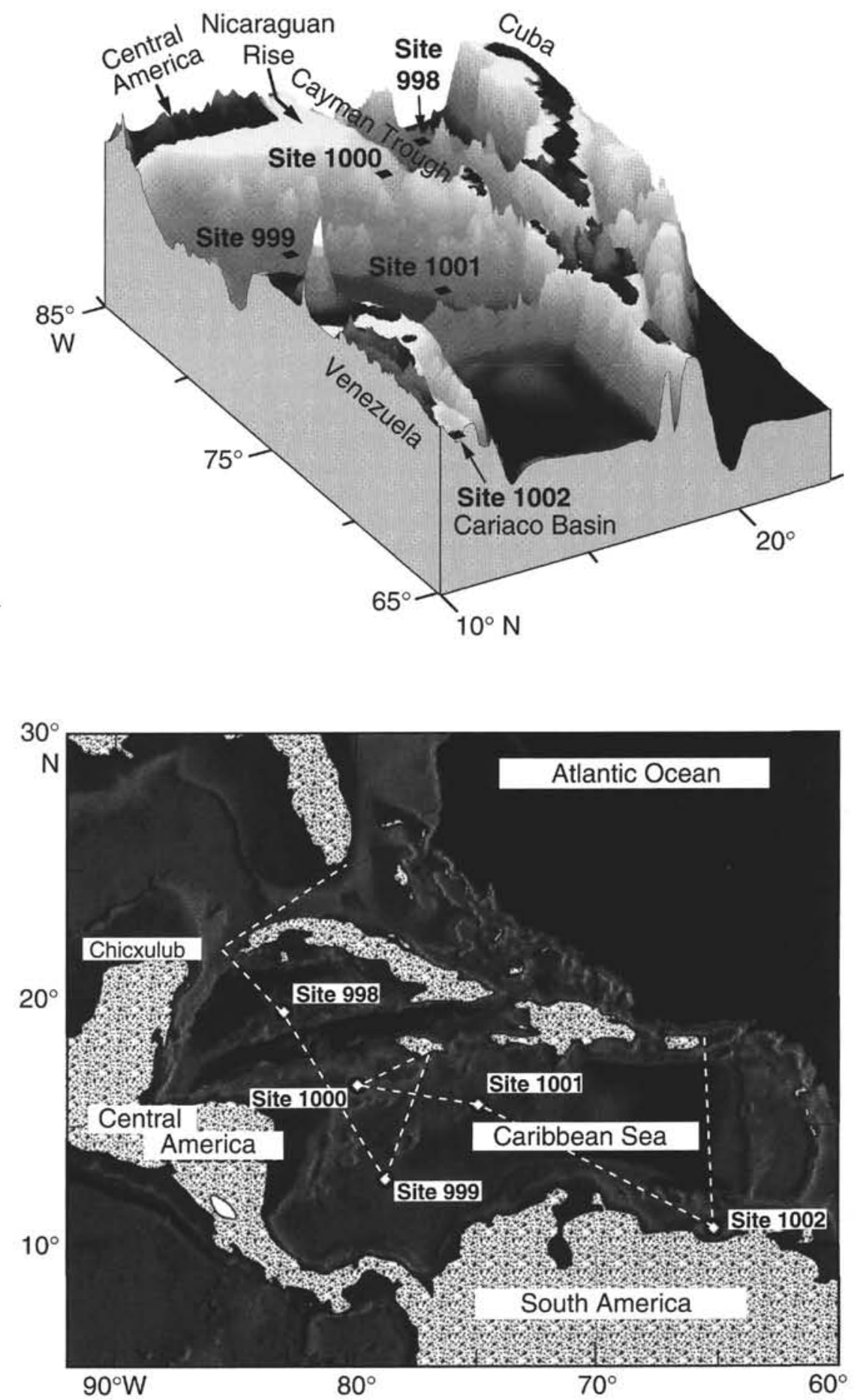

Figure 2. Location of sites drilled during Leg 165.

\section{Neogene}

As expected, there is a strong correlation between carbonate MAR and the water depth of each of the sites: Site 1001 on the Hess Escarpment $(3260 \mathrm{~m}$ ) has the lowest carbonate MARs, and Site 1000 in Pedro Channel $(916 \mathrm{~m})$ has the highest values. Site 998 on the Cayman Rise (3180 m) and Site 999 on the Kogi Rise (2828 m) show a trend of declining carbonate MARs from early Miocene through middle Miocene time, reaching minimum values in the interval of the middle Miocene/upper Miocene boundary (Figs. 3, 4). This pronounced minimum in carbonate MARs corresponds with the carbonate crash interval discussed below. There is a rebound in carbonate MARs during late Miocene time and again during the latest Miocene or early Pliocene at the deeper sites. None of the Caribbean sites shows a significant signal of the late Miocene "biogenic bloom" documented at tropical sites in the Indo-Pacific (e.g., Peterson et al., 1992; Berger et al., 1993; Farrell et al., 1995). The Miocene trend of carbonate accumulation at the shallow Site 1000 does not parallel trends described for the deeper sites.

Site 999 had a major increase in carbonate MARs in the early Pliocene ( 4.6-4.5 Ma), roughly coincident with observed changes in planktonic foraminifer assemblages (see below) (Fig. 4). These changes are roughly coincident with a marked divergence of eastern equatorial Pacific and southwestern Caribbean mixed-layer planktonic foraminifer $\delta^{18} \mathrm{O}$ values (Keigwin, 1982a) and a major shift in the location of eastern equatorial biosiliceous productivity (Farrell et 


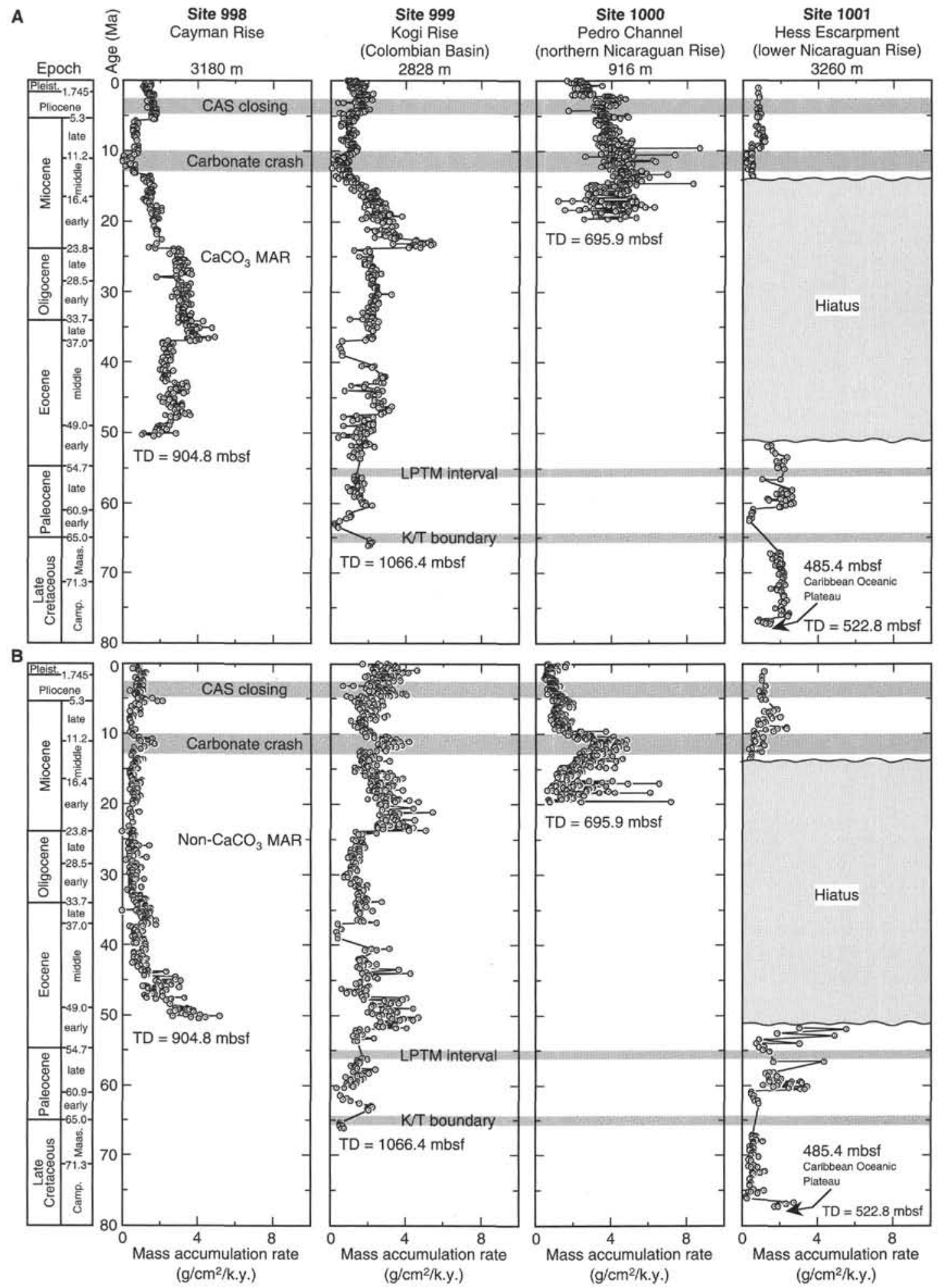

Figure 3. Carbonate (A) and noncarbonate (B) mass accumulation rates (MARs) for Sites 998-1001. TD = total depth. Highlighted: Cretaceous/Tertiary (K/T) boundary interval, Late Paleocene Thermal Maximum (LPTM), middle to late Miocene carbonate crash, and closing of the Central American Seaway (CAS).

al., 1995). Uplift of the Isthmus of Panama and final closure of the Central American Seaway between $\sim 4.5$ and $3.5 \mathrm{Ma}$ is thought to be responsible for these oceanographic changes (Keigwin, 1982a, 1982b; Coates et al., 1992; Farrell et al., 1995).

An important feature of the Pliocene record at Site 1000 is the sharp increase in carbonate MARs in the middle Pliocene. The clos- ing of the Central American Seaway at this time may have had an influence on the Caribbean Current by enhancing the flow rate and inducing topographic upwelling along the NNR. In addition, high sea level during the early to middle Pliocene may have facilitated carbonate bank productivity adjacent to Site 1000 , with off-bank transport of aragonite and high-magnesian calcite enhancing the carbonate 


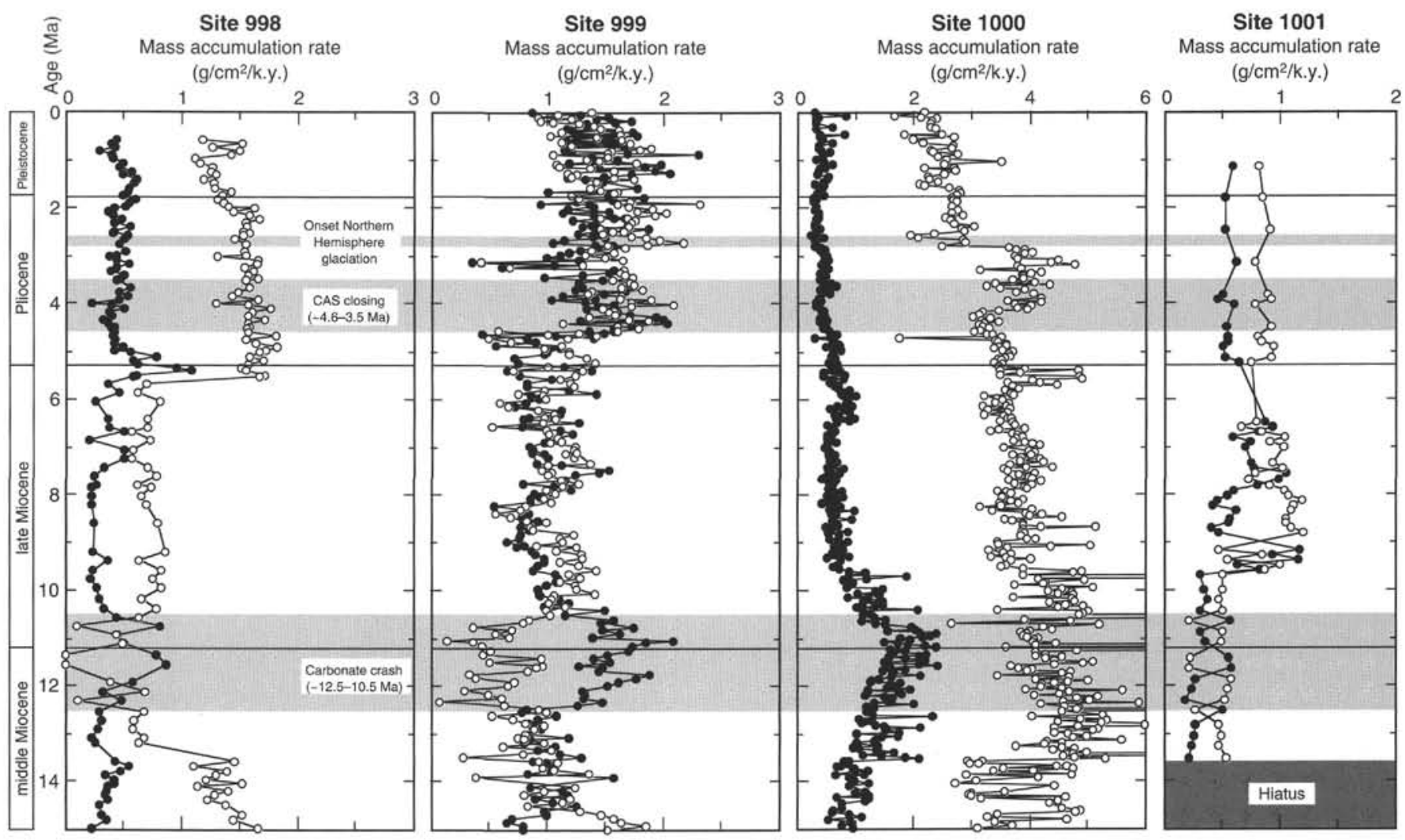

Figure 4. Compilation of sediment mass accumulation rates (MARs) of carbonate (open circles) and noncarbonate (solid circles) fractions for last 15 m.y. at Sites 998, 999, 1000, and 1001. Highlighted intervals show the general timing of the carbonate crash, uplift of the Isthmus of Panama and closing of the Central American Seaway (CAS), and major intensification of Northern Hemisphere glaciation. An unconformity at Site 1001 separates sediments of middle Miocene age $(\sim 13.5 \mathrm{Ma})$ from Eocene age.

MAR. Observed changes in carbonate MARs during the Pliocene may also reflect changes in conveyor-belt circulation and water-mass sources linked to the closing of the Central American Seaway, which might be a causal mechanism for the major intensification of Northern Hemisphere glaciation at approximately 3.2 to $2.7 \mathrm{Ma}$.

Sites 998,999 , and 1000 show a decline in carbonate MARs from late Pliocene through Pleistocene time. This trend is particularly pronounced at Site 1000 in Pedro Channel and may reflect, in part, increased strength (and variability?) of the Caribbean Current following the intensification of Northern Hemisphere glaciation (i.e., significant changes in the flow rate with rising and falling sea level).

Sites 998,999 , and 1000 show a marked increase in noncarbonate MARs at the time of the carbonate crash, near the middle Miocene/ upper Miocene boundary (Fig. 4). This pattern is strong at Site 1000, despite a rather minimal decline in carbonate MARs. At Site 1001, there is a slight increase in noncarbonate MARs associated with the crash. There are marked differences in the noncarbonate MARs between Sites 998 and 999 through the upper Miocene-Pleistocene. The much higher values at Site 999 may reflect two influences: proximity to the Magdalena Submarine Fan and the greater volcanic ash accumulation rates in the Miocene (see below). The influence of the Magdalena Fan at Site 999 may have increased after $8 \mathrm{Ma}$ in response to tectonic activity in the northern Andes of Colombia (Benjamin et al., 1987; Case et al., 1990).

\section{PALEOCEANOGRAPHY}

\section{Late Paleocene Thermal Maximum}

A transient episode of rapid warming during latest Paleocene time, referred to as the "late Paleocene thermal maximum" (LPTM), occurred within a longer term interval of increasing temperatures that culminated in the early Eocene (Zachos et al., 1993). This abbreviated interval of time was marked by abrupt temperature changes from the tropics to the poles. In the southern high latitudes, for example, sea-surface temperatures increased from $14^{\circ}$ to $20^{\circ} \mathrm{C}$ in less than $10,000 \mathrm{yr}$ while deep-water temperatures warmed from $10^{\circ}$ to $18^{\circ} \mathrm{C}$ (Stott et al., 1990; Kennett and Stott, 1991). The LPTM is also marked by a large negative $\delta^{13} \mathrm{C}$ excursion and a mass extinction of deep-water benthic foraminifers (Tjalsma and Lohmann, 1983; Thomas, 1990, 1992; Kennett and Stott, 1991). This episode of extreme high latitude warmth, which lasted for up to several hundred thousand years (Zachos et al., 1993), has previously been detected in only a few deep-sea sequences (e.g., Kennett and Stott, 1991; Zachos et al., 1992; Bralower et al., 1995; Thomas and Shackleton, 1996).

In the tropics, coeval with the $\delta^{13} \mathrm{C}$ excursion and benthic foraminifer extinction event, thermal gradients between the surface and intermediate waters collapsed and benthic foraminifers record a $4^{\circ}-6^{\circ} \mathrm{C}$ warming of intermediate waters (Bralower et al., 1995). Extreme oligotrophy in the equatorial Pacific stimulated a burst of diversification among the surface-dwelling, photosymbiont-bearing planktonic foraminifer genera Acarinina and Morozovella (Kelly et al., 1996). Surface-water temperature gradients between the equatorial Pacific and southern high latitudes decreased to as low as $4^{\circ} \mathrm{C}$ during the LPTM (Bralower et al., 1995). A rapid but short-lived change from high- to low-latitude sources of deep- (and intermediate?) water masses is suspected to be responsible for the extreme warming (Kennett and Stott, 1991; Pak and Miller, 1992).

Uppermost Paleocene sequences recovered during Leg 165 record the impact of the LPTM on the surface and deep waters of the Caribbean. Sites 999 and 1001 (Holes 1001A and 1001B) provide a unique record of the LPTM; for the first time, the event can be observed from 

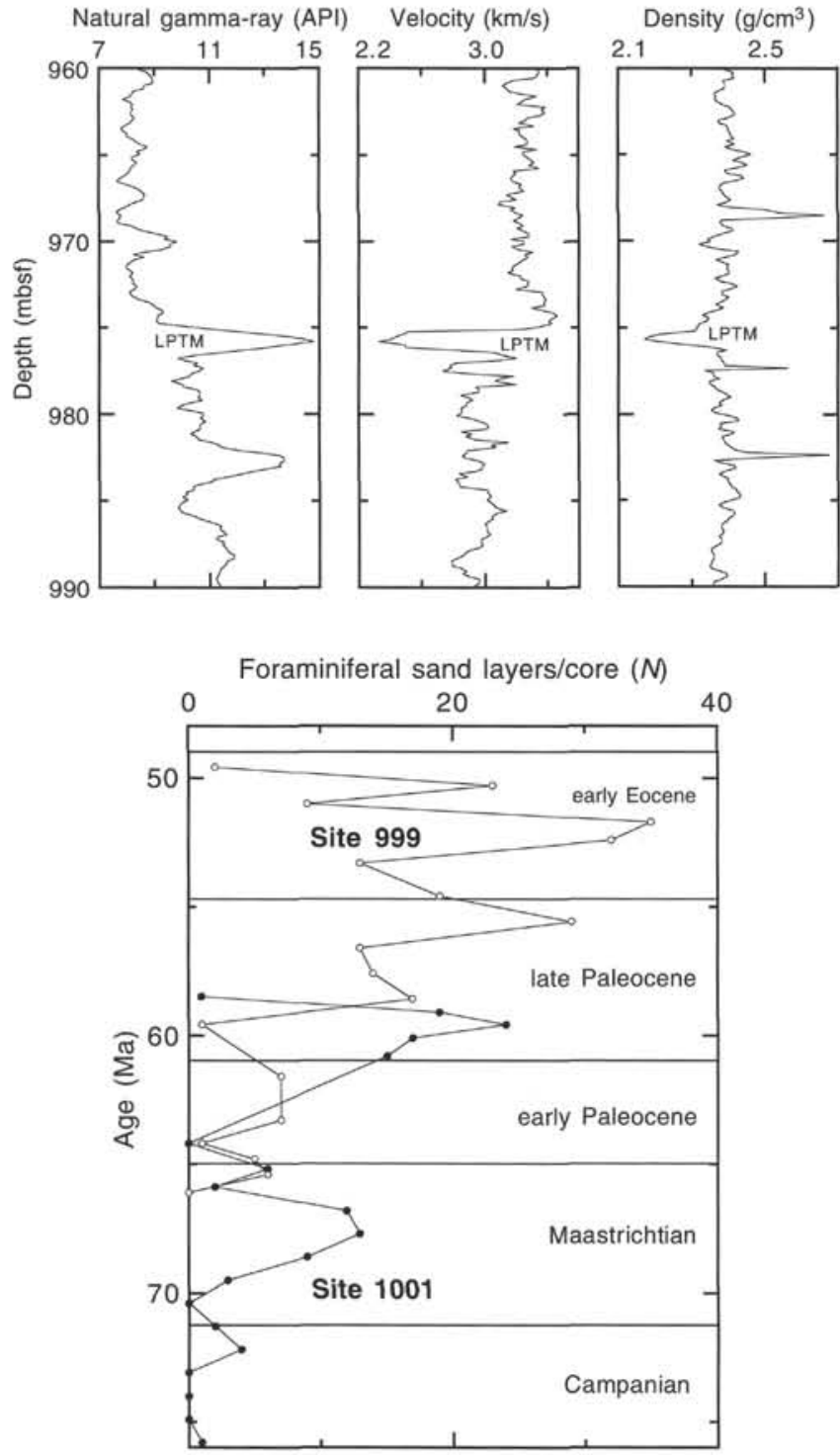

Figure 6. Number of foraminiferal sand layers per core for Sites 999 and 1001.

lithologic and physical properties changes and in downhole logging measurements (Fig. 5). In both sites, this interval corresponds to a 0.5 - to $1-\mathrm{m}$ claystone horizon characterized by significantly lower carbonate content than surrounding chalks and limestones. This claystone shows faint lamination in Site 999 and indications of diminished bioturbation in Site 1001, which is the strongest evidence of reduced seafloor oxygenation in any deep sea LPTM record. Similar sedimentary structures have been observed in a section from Spain (Canudo et al., 1995). Pronounced maxima are seen on gamma-ray and susceptibility records. Interbedded in the claystone are several multicolored volcanic ash horizons that potentially allow correlation between the sections at Site 999 and 1001, and permit precise correlation between the two holes at Site 1001. The claystone unit lies in an identical biostratigraphic position to the LPTM in other tropical sections, between the first occurrence of the foraminifer Morozovella subbotinae and the last occurrence of the nannofossil genus Fasciculithus (e.g., Bralower et al., 1995). Samples immediately below the claystone have been found to contain the benthic foraminifer Gavelinella becariiformis, a species that goes extinct in the LPTM interval

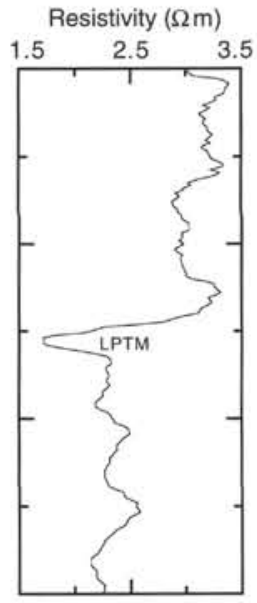

Figure 5. Late Paleocene thermal maximum (LPTM) as observed at approximately $975.5 \mathrm{mbsf}$ in selected downhole measurements from Hole 999B. The elevated gamma-ray counts and relative minimum values of sonic velocity, density, and resistivity are consistent with a 65 -cm-thick claystone interval observed in Section 165-999B-51R-5 ( 977 mbsf). (e.g., Tjalsma and Lohmann, 1983), whereas no specimens of G. becariiformis have been found in samples above the claystone layer in either site.

Because the paleodepths of Sites 999 and 1001 are deeper than most other LPTM sections, these records add important constraints to our knowledge of deep-water circulation and chemistry during the event. Diminished carbonate contents in claystones are thought to reflect shoaling of the lysocline and carbonate compensation depth (CCD) in the LPTM interval. This is corroborated by poor microfossil preservation. Evidence for dysoxia at deep-water Sites 999 and 1001 suggests that only the deepest part of the water column was truly oxygen-deficient, that the Caribbean deep waters were very old, or alternatively, that a source of warm, saline deep waters was nearby. Reduced carbonate flux may be an additional reason for the reduced carbonate content. This is supported by the lack of measurable organic carbon in the claystone at either site, and is compatible with other lines of evidence for surface-water oligotrophy during the LPTM interval (Rea et al., 1990; Kelly et al., 1996). The occurrence of lamination predominantly in the lower part of the record at Site 999 suggests that the onset of the LPTM was sudden and that recovery was more gradual.

The upper part of the LPTM at Site 1001 contains coarser foraminifer-rich layers that resemble the foraminifer- and radiolarianrich layers observed in other parts of the Upper Cretaceous-lower Eocene section at Sites 999 and 1001 (see "Lithostratigraphy" section, "Site 999" chapter; Fig. 6). These 1- to 13-cm-thick layers have sharp nonerosive upper and lower boundaries. This feature suggests that the layers are not turbidite events, but were probably formed by intensified winnowing near the sediment-water interface. We postulate that these winnowed layers reflect active deep-water currents in the Caribbean during times of global warmth in the Late Cretaceousearly Paleogene. Because this was generally a time when deep waters were warm and thermohaline circulation is thought to have been relatively sluggish (e.g., Zachos et al., 1993; Huber et al., 1995), we tentatively conclude that the intensified deep-water circulation that produced this winnowing resulted from mixing water masses with striking salinity differences.

\section{Middle/Late Miocene Carbonate Crash}

An important discovery of Leg 165 is a marked reduction in pelagic carbonate deposition across the middle/late Miocene boundary interval about 10.5-12.5 Ma at Sites 998, 999, 1000, and 1001 (Fig. 7). This well-developed oceanographic event has also been clearly identified in the central and eastern equatorial Pacific by van Andel et al. (1975) and Mayer, Theyer, Thomas, et al. (1985), and on Leg 138 (Lyle et al., 1995; Farrell et al., 1995; Pisias et al., 1995). This 


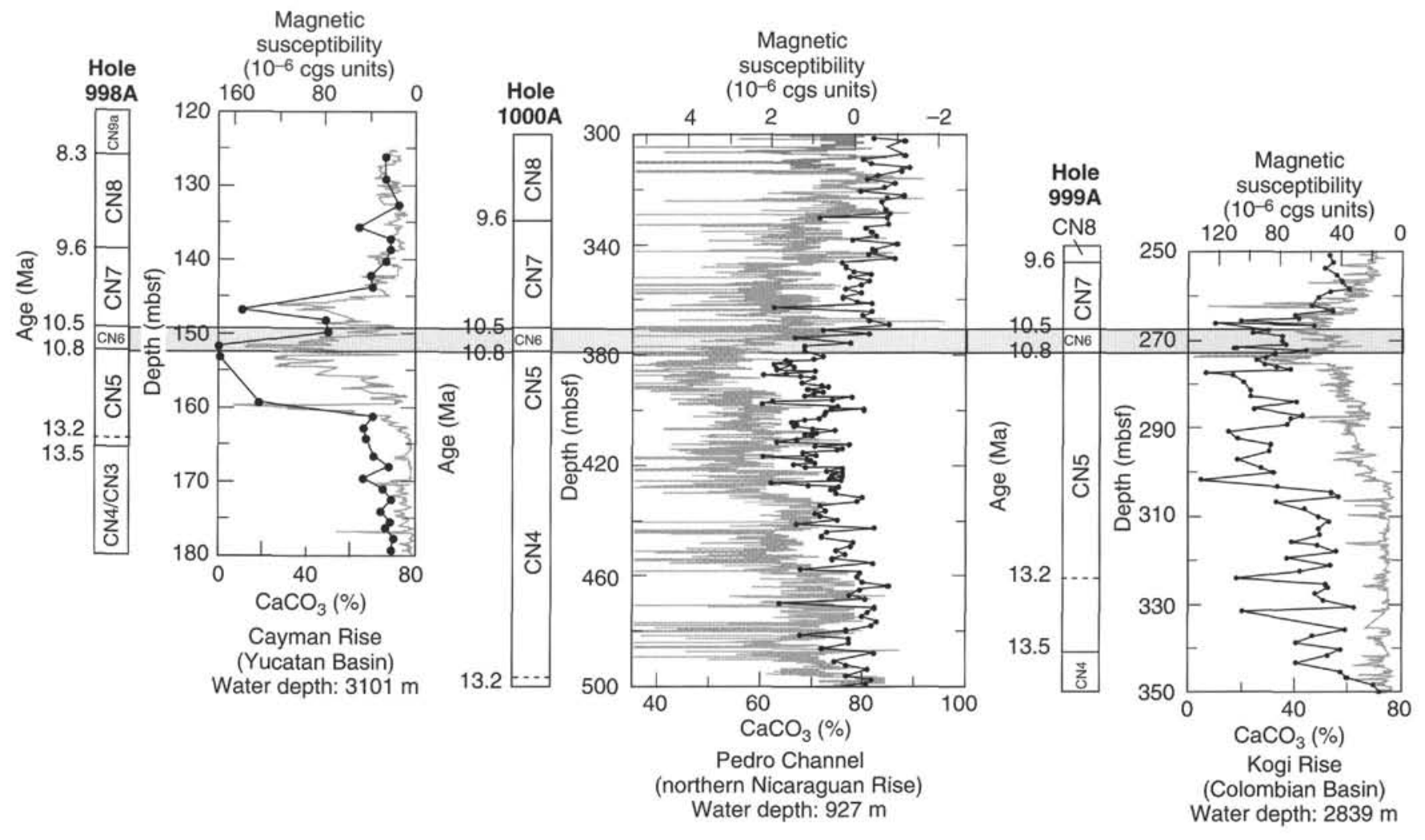

Figure 7. Correlation between $\% \mathrm{CaCO}_{3}$ (solid circles) and magnetic susceptibility (shaded lines) data for pelagic carbonates at Sites 998,999 , and 1000.

event is referred to as the carbonate crash by Lyle et al. (1995). The carbonate records in the equatorial Atlantic Ocean (Ceara Rise, Leg 154; Curry, Shackleton, Richter, et al., 1995) also show that carbonate values decrease dramatically during the same time interval. However, this event had not been previously documented in the Caribbean Sea. Drilling during Leg 138 and Leg 165 revealed that the carbonate crash occurred on both sides of the Central American Seaway, in the eastern equatorial Pacific (Lyle et al., 1995) and the Colombian Basin (Sites 999 and 1001), on the Cayman Rise (Site 998) and, to a lesser degree, on the NNR in Pedro Channel (Site 1000). At Site 1000, the sea bottom $(912 \mathrm{~m})$ is at the base of the permanent thermocline. These new findings will further our understanding of the timing and geographic extent of the event of the carbonate crash event, and will also add to our knowledge of Miocene gateways and sills, circulation, and water-mass source and chemistry.

We suspect that tectonic activity associated with the stepwise closing of the Central American Seaway during the late Neogene was an important variable in the onset of North Atlantic Deep Water (NADW) formation and its role in the evolution of the global ocean circulation and ocean carbonate chemistry, which includes a direct influence on the evolution of Northern Hemisphere climate.

\section{Colombian Basin: Site 999, Kogi Rise (2828 m), and Site 1001, Hess Escarpment $(3260 \mathrm{~m})$}

The initial abrupt decrease in carbonate content at Site 999 occurs within calcareous nannofossil Zone CN5, and is matched by an increase in magnetic susceptibility (Fig. 7). Low carbonate values $(<20 \%)$ persist until after $10.5 \mathrm{Ma}$. The decrease in carbonate values at Site 999 corresponds to a substantial reduction in carbonate accumulation rates and poor preservation of calcareous microfossils. Minimum carbonate MARs occur between 12.4 and 10.6 Ma (Fig. 8). Carbonate dissolution and a shoaling of the lysocline and CCD are suggested as causes of the observed patterns.
At Site 1001 on the Hess Escarpment, slightly above the level approximating the middle/upper Miocene boundary interval, the initial abrupt decrease in carbonate content occurs within calcareous nannofossil Zone CN5. This is matched by an increase in magnetic susceptibility and a decrease in color reflectance in the green 550-nm wavelength. Site 1001 is the deepest site $(3260 \mathrm{~m})$ drilled during Leg 165 and, in contrast to Sites 998, 999, and 1000, low carbonate values $(<40 \%)$ persist until after $9.5 \mathrm{Ma}$ in calcareous nannofossil Zone $\mathrm{CN} 8$. The latest age for low carbonate values in the other sites was Zone $\mathrm{CN} 7$ at approximately $10-10.5 \mathrm{Ma}$. In addition, the sediment sequence deposited during Zone CN7 at Site 1001 is either condensed or incomplete when compared with those of the other sites.

\section{Northern Caribbean: Site 998, Cayman Rise (3180 m)}

At Site 998, the fraction of carbonate preserved in the pelagic sediments decreased precipitously after approximately 11.5 Ma (Fig. 7). Carbonate accumulation appears to have virtually ceased at this site through an interval tentatively centered on about $10.5 \mathrm{Ma}$ (within calcareous nannofossil Zones CN5, CN6, and CN7). Poor preservation of calcareous nannofossils (smear slides) and planktonic foraminifers (washed samples), as well as low carbonate accumulation rates during this interval (minimum between 12.5 and $10.6 \mathrm{Ma}$; Fig. 8 ), suggest that a sudden shoaling of the CCD and carbonate dissolution were responsible for the accumulation of these nearly pure clays.

\section{Subthermocline Depth: Site 1000, Pedro Channel (916 m)}

At Site 1000 , the well-defined carbonate minimum at the very beginning of the late Miocene is at the end of nannofossil Zone CN5 and at the beginning of Zone CN6 (Fig. 7). It corresponds to the lowest accumulation rate of $\mathrm{CaCO}_{3}$ in the Miocene (average $3 \mathrm{~g} / \mathrm{cm}^{2}$ per $1000 \mathrm{yr}$, with a minimum between 12.2 and $10.8 \mathrm{Ma}$ ) and to the highest accumulation rates of non- $\mathrm{CaCO}_{3}$ for the entire Neogene section 

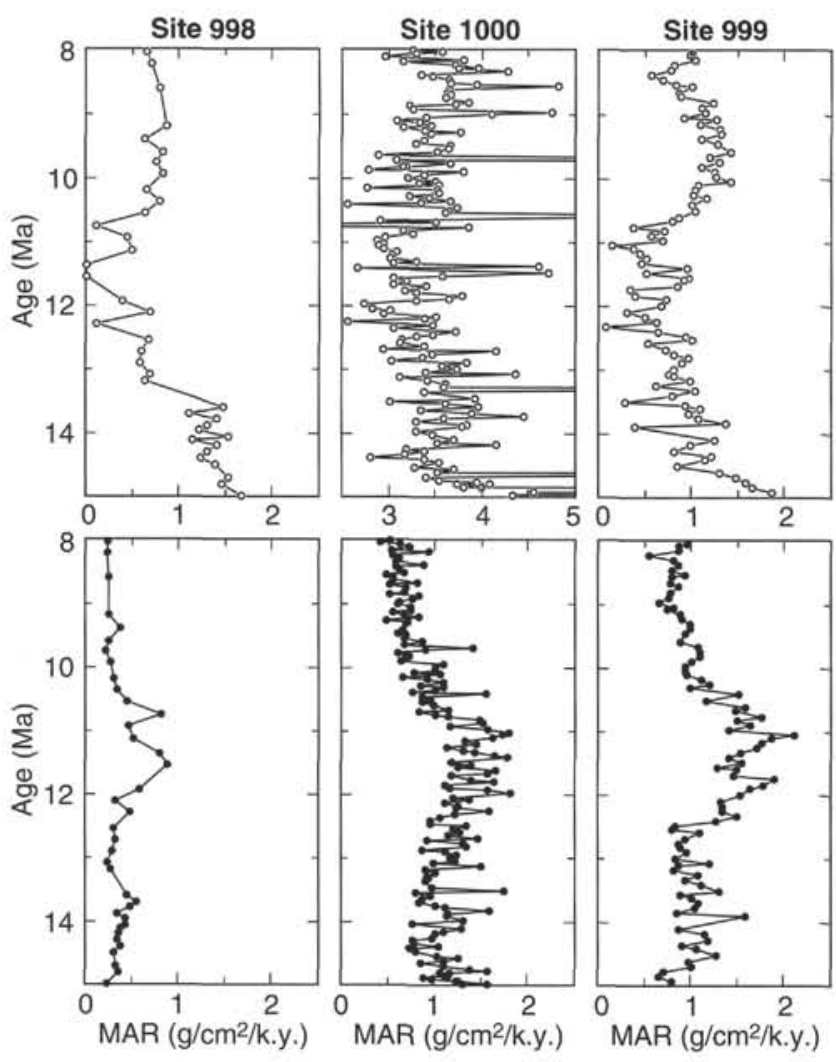

Figure 8. Mass accumulation rates for carbonate (open circles) and noncarbonate (solid circles) components in the interval bounding the middle/late Miocene carbonate crash.

of Site 1000 (Fig. 8). This event appears to be synchronous with the pronounced decrease in carbonate deposition at Sites 999 and 1001 in the Colombian Basin, and at Site 998 on the Cayman Rise (Fig. 7).

At the two deep sites on the south (Site 999) and north (Site 998) sides of the NNR, a substantial reduction in carbonate accumulation rates and the poor preservation of calcareous microfossils suggests that carbonate dissolution and shoaling of the lysocline and CCD are responsible for the observed patterns. However, the paleowater depth at Site 1000 was probably as shallow, or perhaps even shallower, than today (in either case, well above the calcite lysocline). Moreover, preservation of calcareous nannofossils and planktonic foraminifers at Site 1000 does not appear to have deteriorated during that interval. At the present time, the water column at Site 1000, in spite of its relative shallow depth, is just at saturation or slightly oversaturated with respect to aragonite, and at saturation or slightly undersaturated with respect to magnesian calcite (Droxler et al., 1991). It is conceivable, therefore, that the late/middle Miocene, bank-derived, fine aragonite and magnesian calcite suffered some maximum seafloor dissolution at the time of the carbonate crash. Dissolution of bank-derived aragonite and magnesian calcite is observed intermittently during the late Quaternary in the Pedro Channel, the Walton Basin, and the Lesser Antilles at water depths comparable with the depth of Site 1000 and especially deeper than 1100 m (J.P. Schwartz, unpubl. data, 1996; Haddad, 1994; Glaser and Droxler, 1993; Schlager et al., 1994; Reid et al., 1996). Moreover, during the late Quaternary, intervals of known enhanced dissolution of aragonite and magnesian calcite at relatively shallow depths between 1100 and $1800 \mathrm{~m}$ in the periplatform oozes of Pedro Channel, Walton Basin, and the Lesser Antilles (e.g., Holocene, Stage 5e, first half of Stage 6, and the mid-Brunhes dissolution maximum during Stage 11 at $0.4 \mathrm{Ma}$ ) correspond to intervals of major dissolution of calcite-bearing ooze in the deep Venezuelan and Colombian Basins (Haddad, 1994; J.P. Schwartz, unpubl. data, 1996; Reid et al., 1996; Cofer-Shabica, 1987; Prell et al., 1982). The subthermocline water depth of Site 1000 will allow us to study the carbonate crash in a range from intermediate- to deep-water masses.

\section{Noncarbonate Input}

The noncarbonate accumulation rates peak at the end of the carbonate crash at 10.6-10.8 Ma in the four Caribbean sites, and specifically by a factor of 2 at Sites 998,999 , and 1000, each of which is located in a very different depositional regime (Fig. 8). The major decrease in global sea level at $\sim 10.5-11.0 \mathrm{Ma}$ (Haq et al., 1987) appears to be synchronous with the end of the carbonate crash and could explain the high accumulation rates of noncarbonate components at that time. An increase of noncarbonate input into the ocean caused by exposure of the continental shelves may have also contributed to the decrease in calcium carbonate concentration through the middle-late Miocene. However, the initiation of the crash, as indicated by a decrease in $\% \mathrm{CaCO}_{3}$ and $\mathrm{CaCO}_{3}$ MARs, clearly began before an increase in non- $\mathrm{CaCO}_{3}$ MARs (Fig. 8).

\section{Discussion}

The carbonate crash at the middle/late Miocene boundary interval is observed not only within the Caribbean basins, but also across a wide area between the eastern equatorial Pacific and the western equatorial Atlantic Oceans. Its global occurrence appears to be broadly synchronous (the initiation may be more or less synchronous but the nadir is not) and to occur within the end of nannofossil Zone CN5 and the beginning of Zone CN6 (Fig. 9). At Caribbean Sites $998,999,1000$, and 1001 , the onset occurred at approximately 12.4 $\mathrm{Ma}$ and the peak is estimated at about 10.8-11.2 Ma (Figs. 7, 8). In the Peru and Guatemala basins (eastern equatorial Pacific), the marked decrease in $\% \mathrm{CaCO}_{3}$ and $\mathrm{CaCO}_{3}$ MARs began in the interval between 12.0 and 12.75 Ma, marking the onset of the crash in the eastern equatorial Pacific Ocean. The peak of the crash occurred at 9.5 Ma in the eastern equatorial Pacific (Site 846; Lyle et al., 1995), about 1.0-1.5 m.y. after the Caribbean minimum (Fig. 9).

The carbonate crash appears to be also recorded at the Ceara Rise based on the magnetic susceptibility, $\% \mathrm{CaCO}_{3}$, and sediment accumulation rate records (Curry, Shackleton, Richter, et al., 1995). The characteristic susceptibility signature observed in the eastern equatorial Pacific Ocean and Caribbean Sea, coupled with some very coarse carbonate data, is also present at all the Ceara Rise sites across the depth transect, although the deepest site (Site 929) at 4355-m water depth has the strongest record of susceptibility and dissolution. The shallowest site (Site 925) at $3040 \mathrm{~m}$ has the weakest signals of the five sites in the depth transect. Evidence from Sites $927(3315 \mathrm{~m})$ and 926 (3598 m) shows that the onset of the crash may have begun as early as $12.5-13.5 \mathrm{Ma}$ and the peak may have been at about 11.2 11.5 Ma, much more similar to the timing of the Caribbean sites than to the eastern equatorial Pacific sites (Fig. 8).

The causes of the carbonate crash may not lie exclusively in the domain of deep-water source and chemistry. Several lines of evidence from the Caribbean, western equatorial Pacific, and perhaps even the Ceara Rise in the western equatorial Atlantic suggest that the event was more widespread here than in the eastern and central equatorial Pacific, and that it may have influenced the entire water column. In the western equatorial Pacific, a decrease in sedimentation rates began at about $13.0 \mathrm{Ma}$ and reached a minimum 10.0-11.5 Ma at sites spanning 2500-3400 m of water depth (Sites 806, 807, 805, and 803 on the Ontong-Java Plateau; Berger et al., 1993). Two interesting observations about this depth transect are (1) the timing of the sedimentation rate minima is diachronous, from deep to shallow (11.5 Ma at Site 804, 11.0-11.5 Ma at Site 803, 10.0-11.0 Ma at Site $805,10.0-11.0 \mathrm{Ma}$ at Site 807 , and 10.0-10.5 Ma at 806; see fig. 15 


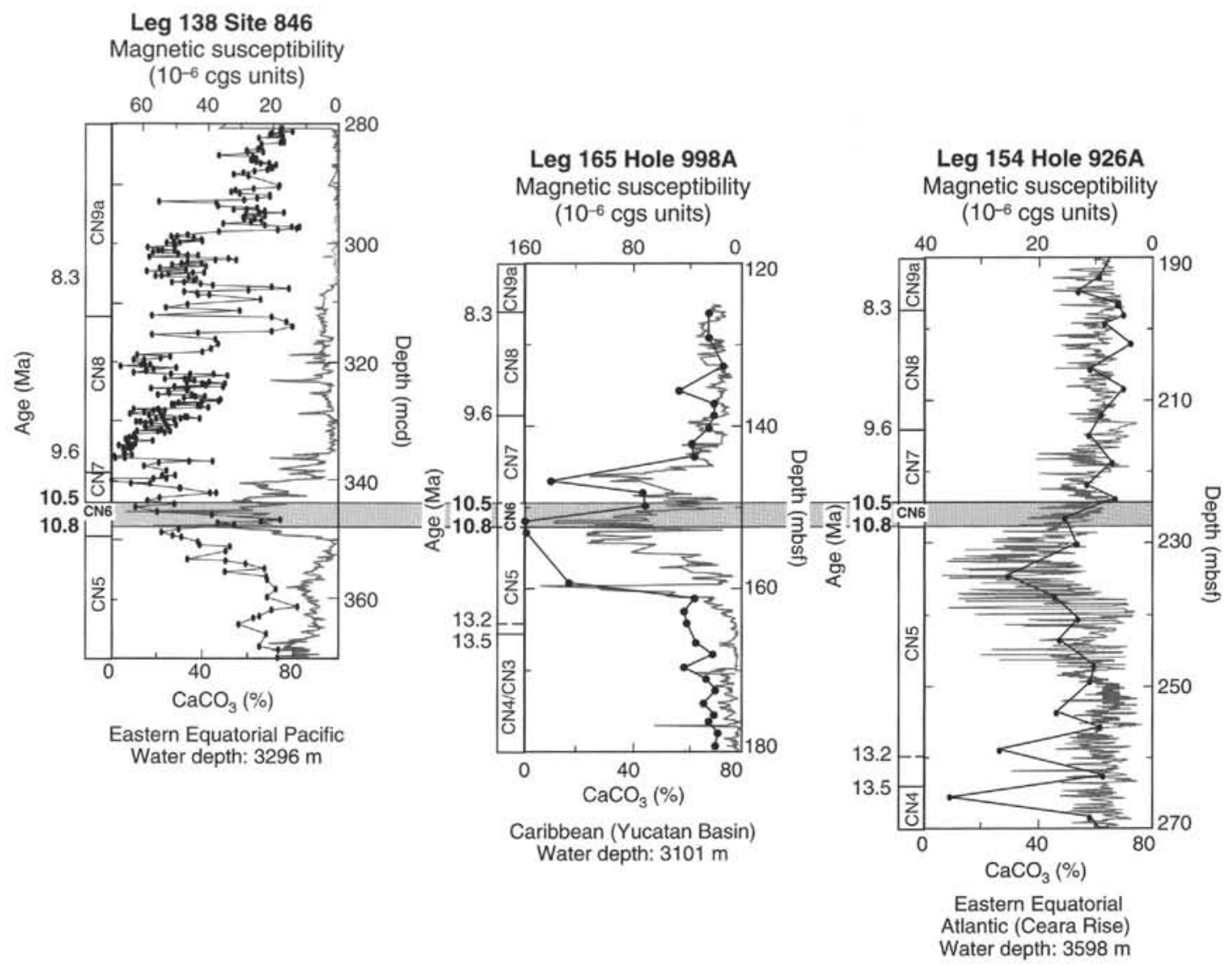

Figure 9. Correlation between $\% \mathrm{CaCO}_{3}$ (dots) and magnetic susceptibility (shaded line) data for pelagic carbonates at Site 998 and comparison with equatorial Atlantic and Pacific sites from previous ODP legs (138 and 154).

in Berger et al., 1993); and (2) the longest duration of the sedimentation rate minima occurs at Sites $807(2805 \mathrm{~m})$ and $805(3188 \mathrm{~m})$.

In addition to the changes in sedimentation rate observed in the western equatorial Pacific, marked changes in the population structure of planktonic foraminiferal assemblages during the time of the middle/late Miocene boundary (about 10.4 Ma, according to the Leg 130 age model; Kroenke, Berger, Janecek, et al., 1991) suggest shoaling of the thermocline (Chaisson and Leckie, 1993). Shoaling of the thermocline could indicate increased upwelling and heightened productivity relative to previous times. The evidence from Caribbean Sites 998 and 999 might suggest that there was a decrease in productivity as recorded by the marked reduction of siliceous microfossils. The lack of supporting evidence in the eastern equatorial Pacific for increased productivity during the carbonate crash interval, however, such as an increase in opal MARs, would tend to discount increased organic matter flux as the cause of this widespread carbonate dissolution event. Somewhat contradictory records are implied from the different data sets, which attests to the complexity of the linkages between the operating physical oceanographic, biological, and chemical systems.

Currently, it is premature to rigidly define the causes of the Caribbean carbonate crash. However, early results from Leg 165 show that the initiation of the carbonate crash $(12.4 \mathrm{Ma}$ ) and its peak (between 11.2 and $10.8 \mathrm{Ma}$ ) in the Caribbean is synchronous with observations from the eastern, central, and western equatorial Pacific, as well as from the equatorial Atlantic. The carbonate crash in the eastern equatorial Pacific seems to have lasted 1.0-1.5 Ma longer. The initiation of NADW appears to have occurred at the same time as the carbonate crash at the middle/late Miocene transition (Wright et al., 1991; Wright and Miller, 1993) and might well be linked to the first partial closure of the Central American Seaway (Duque-Caro, 1990). Further shore-based studies of this interval in Sites 998, 999, 1000, and 1001 and comparisons with sites elsewhere that record this profound change in the carbonate system (e.g., Leg 138 sites in the eastern equatorial Pacific; Lyle et al., 1995; Ceara Rise, Leg 154; Curry, Shackleton, Richter, et al., 1995) should help to develop a scenario that will help us understand its origin.

\section{Biostratigraphic Events Associated with the Closing of the Central American Seaway}

Sinistrally coiled (s) Neogloboquadrina pachyderma appears in the upper Miocene sediments of Sites 999, 1000, and 1001 and disappears in the lower Pliocene section of all these sites, coincident with the increased restriction of the Central American Seaway (Duque-Caro, 1990; Coates et al., 1992). The section at Site 1001 $\left(15^{\circ} 45^{\prime} \mathrm{N} ; 74^{\circ} 54^{\prime} \mathrm{W}\right)$ is compressed and the " $N$. pachyderma (s) event" is only included in two core-catcher samples. However, at Sites $999\left(12^{\circ} 43^{\prime} \mathrm{N} ; 78^{\circ} 46^{\prime} \mathrm{W}\right)$ and $1000\left(16^{\circ} 33^{\prime} \mathrm{N} ; 79^{\circ} 52^{\prime} \mathrm{W}\right)$, the upper Miocene to lower Pliocene sections are expanded, and this normally high-latitude species is found in several samples. This stratigraphic event was also noted by Keigwin (1982a) at DSDP Site 502 $\left(11^{\circ} 29^{\prime} \mathrm{N} ; 79^{\circ} 23^{\prime} \mathrm{W}\right)$. Keigwin (1982a) reasoned that the presence of $N$. pachyderma (s) was not an indication of perennially cool low-latitude sea-surface temperatures, but rather suggested that there was seasonal upwelling of cool water in the region.

Linear interpolation between datums using the shipboard biostratigraphy and age model places the $\mathrm{FO}$ of $N$. pachyderma at $7.5 \mathrm{Ma}$ at Site 999, and at $6.5 \mathrm{Ma}$ at Site 1000. However, age estimates (by interpolation) put the LO of this taxon at $4.7 \mathrm{Ma}$ at both sites. At Site 
999, dextrally coiled specimens are more abundant than sinistrally coiled specimens after $\sim 5.6 \mathrm{Ma}$, whereas at Site 1000 sinistrally coiled specimens are the predominant morphotype through to the last occurrence. Early Pliocene isotopic data from the western Caribbean have been interpreted as indicating increased sea-surface salinity due to restriction of surface circulation by the emerging Central American isthmus (Keigwin, 1982a; Prell, 1982; Keller et al., 1989). The shift in isotopic values is at $4.6 \mathrm{Ma}$, nearly coinciding with the 4.7Ma regional extinction of $N$. pachyderma.

Keigwin (1982b) found no N. pachyderma at Pacific DSDP Site $503\left(4^{\circ} 03^{\prime} \mathrm{N} ; 95^{\circ} 38^{\prime} \mathrm{W}\right)$ in the interval that coincides with its stratigraphic range at Site 502, nor was this species observed through the upper Miocene to lower Pliocene interval at Site $998\left(19^{\circ} 29^{\prime} \mathrm{N}\right.$ $\left.82^{\circ} 56^{\prime} \mathrm{W}\right)$. Its occurrence is limited to a $5^{\circ}$ range, between $11^{\circ} \mathrm{N}$ and $16^{\circ} \mathrm{N}$ (modern positions), which may have corresponded to the boundary between the eastward flowing North Equatorial Countercurrent and the tropical, westward flowing North Equatorial Current, where Coriolis-driven divergence causes upwelling in the modern tropical Pacific. This zone of cool, nutrient-rich water may have extended into the western Caribbean until the progressive shoaling of the Panamanian sill from the late Miocene to the early Pliocene (Duque-Caro, 1990) interrupted upwelling in the Caribbean by restricting surface circulation and ending geostrophic flow of the countercurrent from the Pacific to the Caribbean.

The regional extinction of $N$. pachyderma $(\mathrm{s})$ is followed by a radiation of menardii-form globorotaliids in the Caribbean that does not occur in the Pacific. Finely perforate members of Menardella menardii plexus develop in the early Pliocene, apparently from $\mathrm{Me}$ nardella limbata (Kennett and Srinivasan, 1983). Finely perforate specimens of the ancestral species, $M$. limbata, are frequently observed in the early Pliocene sections of all Leg 165 sites, but the finely perforate derivative species, $M$. exilis, $M$. miocenica, and $M$. pertenuis, have successive FOs at $4.5,3.6$, and $3.5 \mathrm{Ma}$, respectively (Berggren et al., 1985). All of these species become extinct in the late Pliocene, shortly after the major onset of Northern Hemisphere glaciation. It appears that between the isolation of the tropical Pacific and Atlantic and the global cooling that accompanied the Pleistocene glaciations, niches were vacated in the upper water column, perhaps by the Pliocene absence of pulleniatine species and Globorotalia tumida in the Atlantic basin, allowing for the radiation of the M. menardii plexus.

The timing of these events suggests that the emergence of the Central American isthmus had biological consequences in the Caribbean and Atlantic. Further investigation of the ecology of the species affected will undoubtedly shed light on the nature of the changes in the upper water column structure and surface-water circulation patterns that resulted from the closing of the low-latitude marine connection between the Atlantic and the Pacific Oceans.

\section{High-Resolution Latest Quaternary Paleoceanography and Paleoclimatology}

Because of extremely high sedimentation rates in the Cariaco Ba$\sin$, the second largest anoxic basin in the world, its sedimentary sequence provides a wealth of high-resolution information about climatic and oceanographic change. Drilling at Site 1002 resulted in triple-recovery of $170 \mathrm{~m}$ of sediment (to $<250 \mathrm{ka}$ ), along with two additional cores in the upper $\sim 10 \mathrm{~m}$ (Holocene). Much of the cored section is laminated, thereby providing a rare record for testing coupled ocean-climate models and causal mechanisms of rapid climate change.

The recovered hemipelagic sediments are dominated by terrigenous material mixed with varying contributions of nannofossils, diatoms, and foraminifers. The mixed nature of the sedimentary sequence provides a dual opportunity to track simultaneously variations in biologic systematics (e.g., export production, ecosystem structure) as well as physical parameters (e.g., oceanic circulation; input of detrital material both from eolian and fluvial sources) in the tropical Atlantic.

Our results to date indicate that the Cariaco Basin cores will supply a template to study the rates and magnitudes of physical and biological changes at the interannual and millennial time scale for several glacial/interglacial cycles. There appear to be multiple anoxic and oxic depositional regimes, along with episodes of diatom-rich laminated sediment suggestive of strong upwelling conditions. Detailed study of these sequences will yield (1) information regarding variation in the strength and position of the trade wind field during different states of the climate system, (2) the response of the biologic ecosystem to changes in oceanic circulation and ice-volume driven changes in sea level, and (3) the stability of tropical climate during glacial and interglacial states. These and forthcoming results, when interpreted in the context of other ODP high-resolution sites (i.e., Santa Barbara Basin, Saanich Inlet), will improve our understanding of the physical and biological linkages within the climate-ocean system and provide for comparison between marine and ice-core records of climate variability.

\section{VOLCANIC ASH LAYERS}

The great abundance of volcanic ash layers in Caribbean sediments cored during Leg 165 was a largely unexpected discovery. Volcanic ash in sediments of the region had been noted during Leg 15 drilling, but a systematic pattern of the spatial and temporal distribution of tephra was not apparent at that time, owing to the very poor core recovery (Edgar, Saunders, et al., 1973). During Leg 165 a total of $78.1 \mathrm{~m}$ of volcanic ash layers was recovered, including $46.3 \mathrm{~m}$ at Site 999 on the Kogi Rise. A total of 2019 volcanic ash layers was documented, which represents $1.0 \%-4.4 \%$ of the sediment thickness. In addition, sedimentary, geochemical, and smear-slide studies have shown that a dispersed ash component constitutes an even larger fraction, ranging from $10 \%$ to $20 \%$ of the sediment in some lithologic units. The large volume of volcanic ash layers in the sediments has manifold implications for Caribbean geology. They are important indicators of the timing and magnitude of volcano-tectonic activity, both at the plate margins and also possibly of intra-plate volcanism related to the evolution of the Caribbean Oceanic Plateau. Inorganic geochemistry studies during Leg 165 have demonstrated further that the discrete ash layers and a dispersed ash component have had a profound effect on the compositional gradients of pore waters in Caribbean sediments as well as on the bulk sediment composition. Finally, the coincidence of several of the major explosive volcanic episodes with sudden climate cooling events in the geologic record inevitably leads to speculation about possible linkages.

The occurrence of ash layers in deep-sea sediments is frequently displayed in terms of the number of ash layers per million years. In the Caribbean, as well as in most other regions of the world ocean, ash layers show a great range in thickness, and thus the number of layers is a strictly relative value. Therefore, we have chosen instead to present the volcanic ash layer data in terms of the volcanic ash accumulation rate $(\mathrm{cm} / \mathrm{m}$.y.) for the four sites at which volcanic ash layers were recovered during Leg 165 (Fig. 10). The figure shows that five prominent episodes of explosive volcanism are recorded in the Caribbean sediments, and that they can be correlated between sites.

One of the more exciting results of Leg 165 is the opportunity to improve the geomagnetic polarity time scale (GPTS) afforded by the large number of volcanic ash layers recovered at Sites 998, 999, 1000 , and 1001. Many of these layers contain unaltered phenocrysts of biotite and are therefore amenable to radiometric dating. High precision ${ }^{40} \mathrm{Ar} /{ }^{39} \mathrm{Ar}$ dates currently provide the critical datums for recent revisions to the time scale. There are currently fewer than ten datums or tie points in the interval between 5 and $85 \mathrm{Ma}$ in the most recent compilation (Cande and Kent, 1995), and these are of variable quali- 

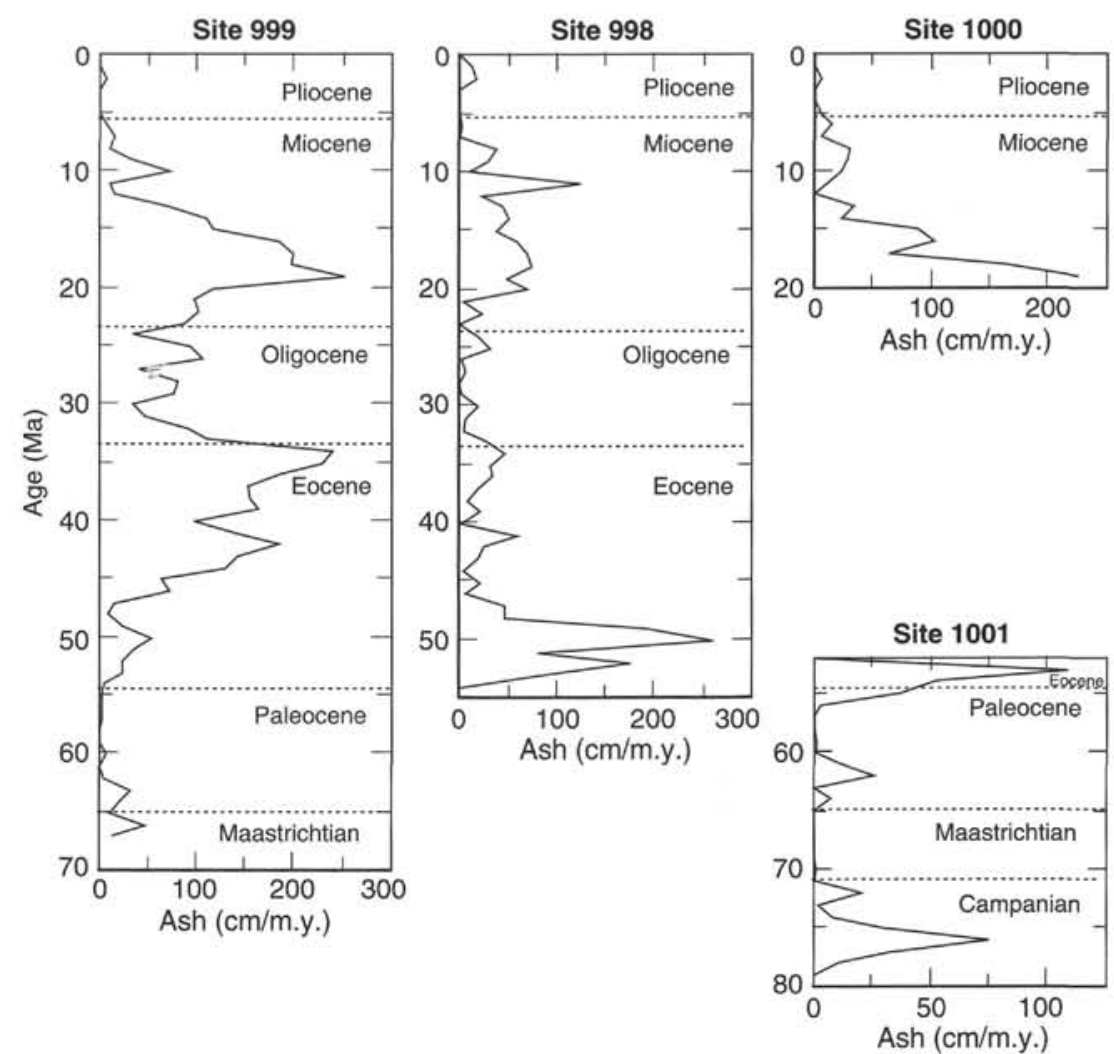

Figure 10. Distribution of volcanic ash layers at four sites drilled during Leg 165: Site 999 on the Kogi Rise in the Colombian Basin, Site 998 on the Cayman Rise, Site 1000 on the upper Nicaraguan Rise, and Site 1001 on the Hess Escarpment. The figure shows the accumulation rate of megascopic volcanic ash layers as $\mathrm{cm} / \mathrm{m}$.y. The data are not corrected for core recovery because core recovery, in general, was excellent and close to complete in much of the cored section. The distribution of volcanic ash layers defines five volcanic episodes: (1) early to middle Miocene, (2) middle to late Eocene, (3) late Paleocene to earliest Eocene, (4) early Paleocene, and (5) late Campanian.

ty. The number of tie points could be quadrupled by the dating of ashes sampled on Leg 165. Integrated post-cruise ${ }^{40} \mathrm{Ar} /{ }^{39} \mathrm{Ar}$ dating, biostratigraphic, paleomagnetic, isotope, and cyclo-stratigraphic studies on volcanic ash layers and sediments recovered from this leg will lead to major improvements in the Cenozoic and Mesozoic time scales.

\section{Miocene Volcanism}

Beginning in the earliest Miocene and extending through the middle Miocene, the western and central Caribbean received silicic ash fallout that defines a major volcanic episode at Sites 998, 999, and 1000 , with ash accumulation rates ranging up to $2.5 \mathrm{~m} / \mathrm{m}$.y. These ash layers range up to tens of centimeters in thickness and are composed almost exclusively of rhyodacitic to rhyolitic bubble-wall glass shards, with a minor phenocryst assemblage of feldspar, quartz, and biotite. Texturally, these ashes are typical of co-ignimbrite ash fall deposits, representing distal fallout from major ignimbrite-forming eruptions. As shown by the ash accumulation rates (Fig. 11), the principal fallout axis for this episode extends eastward from Central America and over the Kogi Rise (Site 999).

During drilling on DSDP Leg 66 ragr the Middle America Trench off Acapulco, Mexico, the early Miocene ( 17 Ma) episode of explosive volcanism was recorded at forearc Sites 493 and 489 , with a peak abundance of up to 10 layers per m.y. (Cadet et al., 1982a, 1982b). Drilling in the forearc region near the Middle America Trench off Guatemala on DSDP Leg 67 also documented an early to middle Miocene ( $15 \mathrm{Ma})$ volcanic ash peak at Sites 495 and 496 with eight to 10 layers per m.y. (Cadet et al., 1982b). In comparison, the peak frequency of the Miocene episode at Site 1000 in the Caribbean is 29 layers per m.y.; at Site 999 on the Kogi Rise it is 46 layers per m.y.; and at Site 998 on the Cayman Rise the frequency is eight layers per m.y., or similar to that near the Middle America Trench.

At Sites 998, 999, and 1000, the aggregate thickness of Miocene ash layers is 650,1663 , and $700 \mathrm{~cm}$, respectively. The Miocene ash thickness at the sites drilled on Leg 66 and Leg 67 is likely to be comparable with that of Site 998, although no exact data are available. The thickest ash layer was recovered at Site 999, indicating that the principal fallout axis of the Miocene explosive volcanism episode lies at this latitude, and that the southern half of the deposit is thus unsampled (neither DSDP Sites 154 or 502 penetrated to this level).

The area encompassing these sites and the sites in the Middle America Trench to the west is in excess of $1.3 \times 10^{6} \mathrm{~km}^{2}$, with megascopic ash layer fallout thicknesses greater than $6 \mathrm{~m}$. A first-order estimate made of the total volume of ash represented by the Miocene volcanic ash layers recovered on Leg 165 is $10^{5} \mathrm{~km}^{3}$. However, the thickness of ash fall layers typically shows an exponential decrease with distance from source; consequently, a large fraction of the volume is represented by thin distal layers with very great areal extent (Pyle, 1989). Thus, this preliminary estimate is likely to represent the minimum quantity of tephra fall associated with this episode of explosive volcanism.

The dispersal pattern clearly indicates a source region in Central America for the Miocene volcanic ash layers, implying an eastward transport in the atmosphere (Fig. 63, "Site 998" chapter, this volume). This may at first seem counterintuitive, given the very strong tradewinds blowing to the west in the Caribbean region. However, empirical evidence from historic eruptions, as well as the tropical at- 


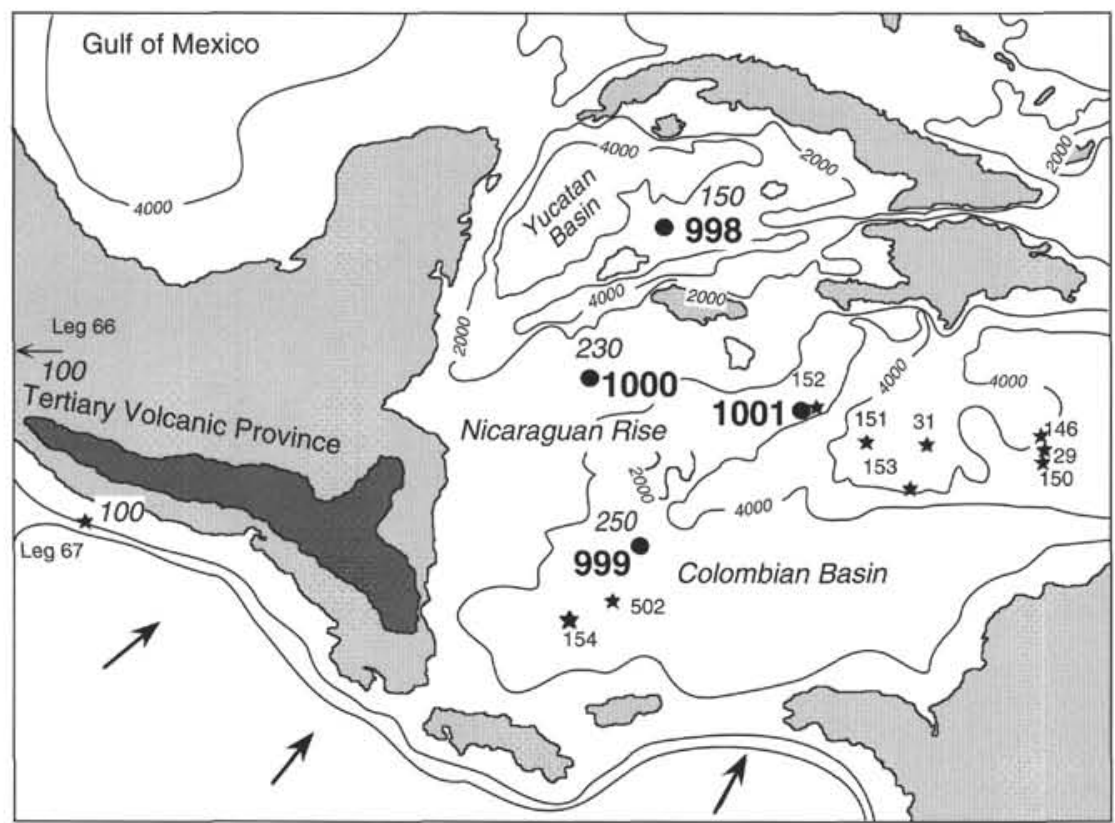

Figure 11. Reconstruction of the paleogeography of the Caribbean region at the time of the eruption of the early to middle Miocene volcanic episode recorded in Caribbean sediments. The Caribbean and eastern Pacific sites that have recovered a record of volcanic ash layer deposition from the early to middle Miocene episode include DSDP Leg 66, Sites 493 and 489, near the Middle America Trench off Mexico (Cadet et al., 1982a), Leg 67, Sites 495 and 496, off Guatemala (Cadet et al., 1982b), as well as Leg 165, Sites 998. 999 and 1000 . Numbers in italics refer to the peak accumulation rate of volcanic ash $(\mathrm{cm} / \mathrm{m} . \mathrm{y}$.) at each site; values for Pacific sites are inferred. The figure also shows the region of major silicic ignimbrite volcanism on the Chortis Block in Central America in the Tertiary (Weyl, 1980). This province marks the likely source region of the Miocene episode. The map is based on the assumption that a $750-\mathrm{km}$ transcurrent motion in the Cayman Trench has taken place in postMiocene time (Rosencrantz and Sclater, 1986). Stars indicate the locations of other DSDP sites. mospheric circulation pattern (Sigurdsson et al., 1980), indicates the eastern transport of ash following major explosive events. Tephraladen eruption columns from highly energetic eruptions attain heights of several tens of kilometers in the atmosphere, and thus deliver ash to the lower stratosphere, well above the tropopause. The dominant circulation at this level in the tropics is to the east for most of the year, leading to dispersal of tephra from Central American eruptions over the eastern and central Caribbean, as observed in the case of Miocene tephra fall layers recovered on Leg 165.

This tephra record most likely correlates with a major episode of Miocene silicic volcanism in Central America, principally in Guatemala, Honduras, El Salvador, and Nicaragua, where widespread, but little studied, deposits of ignimbrites exceed $2 \mathrm{~km}$ in thickness (Reynolds, 1980; Weyl, 1980). On the basis of the biostratigraphic record, the Miocene volcanic episode begins at about 20-22 Ma and terminates at $11 \mathrm{Ma}$. In Central America, the initiation of the Miocene ignimbrite episode has been dated by the K/Ar method at $19 \mathrm{Ma}$, with vigorous activity persisting to less than $10 \mathrm{Ma}$ (Donnelly et al., 1990).

The Miocene volcanic episode provides additional evidence for a global event at this time, as first proposed by Kennett and Thunell (1975), based on a compilation of tephra layers from marine sediments. They proposed that explosive volcanism had increased substantially during the past $2 \mathrm{~m}$.y. and that there was also an important episode during the middle Miocene ( 12-14 m.y.). Further refinement of their data set to remove DSDP sites that had migrated toward volcanic sources and add new data resulted in the definition of widespread volcanic episodes in the Quaternary, middle Miocene ( 1416 m.y.), latest Miocene to early Pliocene ( 3-6 m.y.) and late Miocene ( 8-11 m.y.; Fig. 12A). Removal of sites that were moving toward volcanic sources caused a reduction in the size of the original middle Miocene peak and a general broadening of its limits. The modified record actually shows a very broad, subdued zone of increased explosive volcanism extending from the early to middle late Miocene (Fig. 12A).

It is useful to compare more recent tephra records from DSDP and ODP drilling with both the global compilation and the new results from Leg 165. Of particular interest are results from DSDP Legs 66 and 67 from the Middle America Trench Transect, west of the Central American arc (Cadet et al., 1982a, 1982b). Leg 67 results show peaks in the occurrence of ash layers during the Pleistocene, Pliocene, and early Miocene. Similarly, Leg 66 results shows a peak during the Pleistocene, although the Pliocene peak is reduced and the Miocene peak appears more restricted to the early to middle Miocene boundary. However, correspondence between the Miocene tephra peak recorded west of the Central American arc and the new Leg 165 results to the east in the Caribbean is generally quite good.

A somewhat puzzling aspect of the comparison of these records is the apparent lack of Pliocene-Pleistocene peaks in ash occurrence in the Caribbean sites (Fig. 12F) compared with the Middle American Trench sites (Fig. 12B, C). A possible explanation for this observation may be in a filtering effect imparted by the contrast in transport direction at different levels of the tropical atmosphere. We speculate that the Pliocene-Pleistocene peak in ash layer frequency recorded at the Middle American Trench sites (Leg 66 and 67) may reflect numerous explosive eruptions whose tephra was dominantly transported in the tradewinds because of relatively low eruption column heights (Fig. 13). Smaller explosive eruptions may not have had sufficient magma discharge rates to generate convective eruptive plumes that penetrated into the stratosphere. Consequently, the majority of tephra was dispersed to the west. In contrast, eruptions during the early-middle Miocene episode may have had much higher mass eruption rates that enabled the development of high-altitude stratospheric plumes and subsequent ash transport to the east (Fig. 13). Studies of large-volume explosive eruptions indicate that there is good correlation between the mass eruption rate and the total erupted volume (Carey and Sigurdsson, 1989). Thus, eruptions capable of penetrating high into the stratosphere would be expected to produce enormous volumes of tephra for dispersal into the Caribbean. Eruptions of this magnitude are also likely to produce tephra fall to the west, as part of the tephra volume is entrained and carried in the prevailing trade winds. This could explain why the Miocene peak is preserved on both sides of the Central American arc, whereas the Pliocene-Pleistocene activity is recorded mostly to the west.

Other Pacific tephra records show interesting similarities to the Leg 165 results. For example, the Japan Trench Transect of DSDP Leg 57 shows a distinct peak in ash layers during the early Miocene, in good agreement with Site 999 (Fig. 12D). The Leg 57 results indicate similar numbers of tephra layers during the peak Miocene episode to those found in the Leg 165 sites; one should note, however, that the Leg 57 sites are much more proximal to sources $(200 \mathrm{~km}$ compared with $>1000 \mathrm{~km}$ for Leg 165 sites). In general, the available tephra records, combined with land-based information, appear to suggest increased explosive volcanism during the Miocene, and it has been proposed that such episodes are synchronous on a global scale 
Figure 12. Comparison of marine tephra records from (A) Kennett et al. (1977) global compilation of ash layers in DSDP cores after correction for sites moving toward volcanic sources, expressed as number of ash layers per N Zone; (B) Leg 67 Middle America Trench Transect (Cadet et al., 1982b); (C) compilation of ash layers from Leg 66 Middle America Trench Transect (Cadet et al., 1982a); (D) Leg 57 Japan Trench Transect (Cadet and Fujioka, 1980); (E) K-Ar dates of volcanic rocks from Central America (Kennett et al., 1977); and (F) Site 999. Miocene peaks from Site 999 are shown as shaded regions across the diagram for comparison.

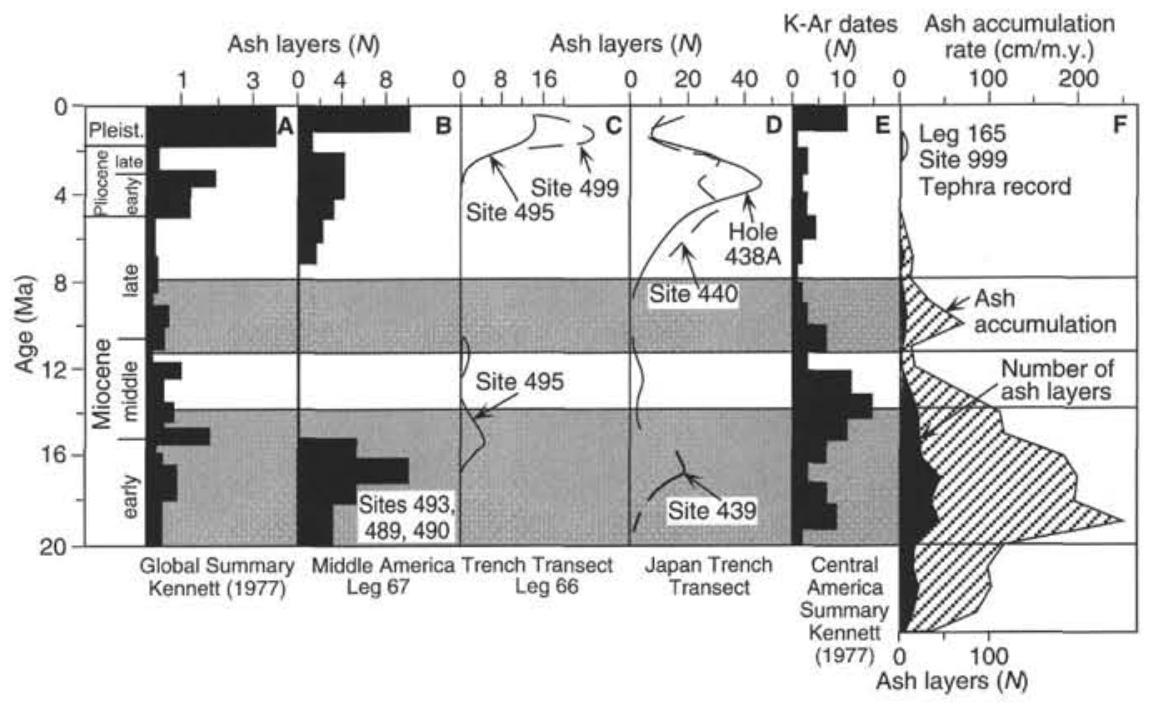

volcanic ash layers are particularly abundant at Site 999 on the Kogi Rise, where the Eocene episode has a peak accumulation rate equal to the Miocene episode ( $250 \mathrm{~cm} / \mathrm{m} . \mathrm{y}$.; Fig. 10). Although the duration of the Eocene episode is greater than the Miocene event, the overall accumulation of the two episodes is closely comparable. The Eocene episode is also documented at Site 998 on the Cayman Rise, and its overall distribution in the Caribbean sediments appears to be similar to that of the Miocene episode, with a main east-trending dispersal axis over the Colombian Basin in the region of the Kogi Rise. The Eocene episode, therefore, is probably from a similar source region as the Miocene event, in the ignimbrite-forming eruptions on the Chortis Block in the Central American arc. The initiation of the Eocene episode may be related to plate tectonic rearrangements in the Pacific. The abrupt change in the direction of Pacific Plate motion at $43 \mathrm{Ma}$ to a more western direction is recorded by the bend $\left(60^{\circ}\right)$ in the Hawaiian hot-spot chain (Atwater, 1989). Such a shift is likely to have had effects on the relative motion of the opposing Farallon Plate and thus on subduction in the Middle America Trench. We tentatively suggest that the middle Eocene episode of Central American arc volcanism was tied to these plate tectonic readjustments.

\section{Cayman Volcanic Arc}

Drilling at Site 998 on the Cayman Rise led to recognition of a third major volcanic episode in the early Eocene (Fig. 10). These Eocene ashes are silicic in composition and have calc-alkaline affinities; in addition to numerous ash fall layers, however, many volcaniclastic turbidite layers derived from a relatively local source are also present (Fig. 63, "Site 998" chapter, this volume). The discovery of early Eocene ash fall layers and associated volcaniclastic turbidites at this site has important implications for the origin and evolution of the Cayman Ridge (Fig. 63, "Site 998" chapter, this volume). Taken together, these types of volcaniclastic deposits indicate a relatively lo$\mathrm{cal}$, and at least in part a subaerial volcanic source, with arc affinities based on petrographic and geochemical evidence. One can see from the stratigraphic distribution of Eocene ash layers that the rate of local island-arc volcanism increases downhole into the early Eocene (Fig. 10), and that it probably extends at least into the Paleocene in this region. Therefore, the seismic reflector that was identified as basement at a sub-bottom depth between 1020 and 1070 mbsf at Site 998 (see "Seismic Stratigraphy" section, "Site 998 " chapter, this volume) probably represents volcanic rocks, overlain by interbedded volcaniclastics and pelagic-hemipelagic sediments. Volcanic ash fall layers of early Eocene age were also found at Site 999 in the Colombian Basin and immediately below the Eocene/Miocene unconformi- 


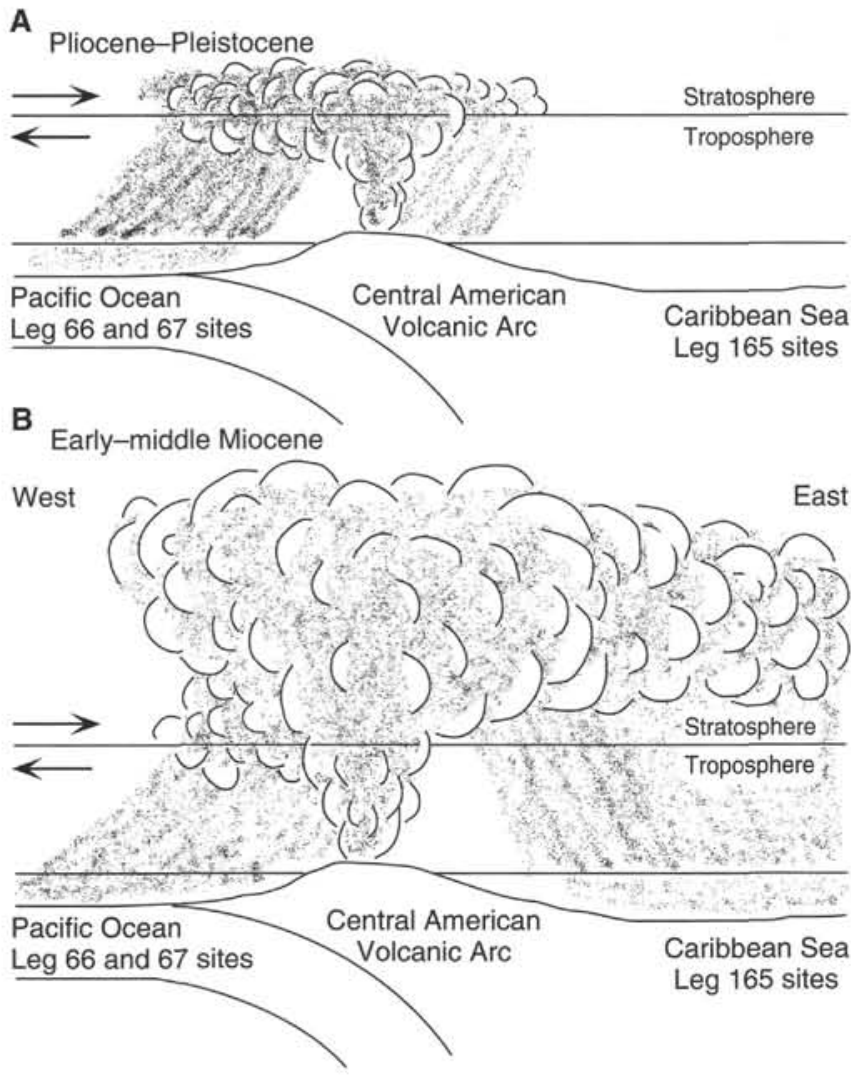

Figure 13. Contrasting transport and depositional processes for (A) moderate and (B) large-scale explosive eruptions from the Central American volcanic arc. Moderate-sized eruptions produce column heights that reach to or above the tropical tropopause. Transport of tephra is predominantly to the west (Pacific Ocean) in the prevailing trade winds. Large-scale explosive eruptions produce high-altitude volcanic plumes that inject large quantities of tephra to stratospheric levels with consequent transport and deposition to the east (Caribbean Sea). The abundance of tephra layers in Leg 165 Caribbean Sea drill sites may reflect very large magnitude eruptions during the early to middle Miocene peak in explosive volcanism.

ty at Site 1001 on the lower Nicaraguan Rise (Fig. 10). These other occurrences also probably relate to Cayman arc volcanism or its eastern extension in Hispaniola or southernmost Cuba.

Support for a volcanic arc origin of the Cayman Ridge comes from both geophysical studies and dredging. The area, including the Cayman Rise and Cayman Ridge to the south, is a region of high positive magnetic anomalies on the order of 100-200 nT and a gravity high of 50-100 mGal (Westbrook, 1990). Both of these anomalies follow the physiographic trend of the rise. The Cayman Ridge consists of up to $20-\mathrm{km}$-thick crust, and rocks dredged from the north wall of the adjacent Cayman Trough are volcanics, metavolcanics, and granodiorites of 59-69 Ma K/Ar ages (Maastrichtian to Paleocene), suggesting a buried Late Cretaceous to Paleocene volcanic arc, overlain by carbonates of Paleocene to Eocene age (Perfit and Heezen, 1978). Rosencrantz (1990) considers the Cayman Rise and Cayman Ridge, as well as the Camaguey Trough, as crustal domains of common origin, as supported by gravity data (Bowin, 1976). The Cayman Ridge probably represents Cayman Rise crust, but the development and elevation of the ridge and its structural separation from the rise can be attributed to rifting and plate motion as part of a wide zone of strike-slip motion, now focused in the Oriente transform fault in the Cayman Trough to the south. Alternatively, the rise may represent a backarc region behind the volcanic Cayman Ridge arc. The graben structures separating the ridge and the rise may reflect the tectonic movement during the earliest stages of Cayman Trough development, or they may be a consequence of strike-slip faulting at or near the Caribbean/North American Plate boundary. If the Cayman Trough began to open in the middle Eocene, then the ridge had most likely formed as a topographic feature before middle Eocene time (Rosencrantz, 1990). However, the evidence of Oligocene and older shallow-water carbonates dredged from the ridge indicates subsidence by Miocene time, whereas younger carbonates are of both deepand shallow-water origin (Perfit and Heezen, 1978). Carbonates of post-Miocene age, recovered by drilling at Site 998 , are, however, all of pelagic origin.

The origin of the Cayman Rise is linked by most workers to the evolution of the Greater Antilles volcanic arc and the development of the northern boundary of the Caribbean Plate. In these models, the Caribbean Plate migrated east-northeast during the Late Cretaceous and the early Cenozoic, subducting oceanic crust of the proto-Caribbean beneath it, and thus generating the Greater Antilles volcanic arc. Evolution of the Early Cretaceous Greater Antilles arc is envisaged as a result of subduction from the south, followed by a polarity reversal of subduction in Late Cretaceous, with subduction of the North American Plate beneath the Caribbean Plate (Lewis and Draper, 1990). This reversal may have occurred between 84 and $110 \mathrm{Ma}$, but volcanism persisted in some of the Greater Antilles islands until the early Eocene. The tectonic configuration that gave rise to the Eocene volcanism is unclear, but this late stage of Greater Antilles volcanism is of particular relevance to our findings of extensive volcaniclastic deposits at Site 998.

Gealey (1980) considered the Cayman Rise and Cayman Ridge as a part of the Greater Antilles arc, which had rifted apart during intraarc spreading in the Yucatan Basin, separating the Cayman Rise from Cuba in the Paleogene (55-65 Ma). This is consistent with the fanshaped or northeast-southwest trend of magnetic anomalies in the Yucatan Basin (Hall and Yeung, 1980). The rifting event would have led to migration of the Cayman Rise to the southeast, relative to the Yucatan and Cuba over a period of 15-20 m.y., from the Maastrichtian to the Eocene. Morris et al. (1990) have also proposed that the Cayman Ridge evolved as an arc over a south-dipping Late Cretaceous subduction zone whose activity had largely ceased by Maastrichtian time. These models are problematic in that rifting of the Cayman Rise and Cayman Ridge from Cuba, and backarc spreading behind an active Cuban arc, requires the presence of younger volcanics on Cuba than on the ridge; Site 998 findings indicate the contrary. Pindell and Barrett (1990) considered the Cayman Rise as the western part of an east-trending magmatic arc that was active into the Eocene, extending into the Sierra Maestra and Cordillera Central of southern Cuba. In the east-trending Sierra Maestra in the Oriente province of Cuba, igneous rocks are extensive mafic and felsic volcanics and early Eocene granitic intrusives; thus, Lewis and Draper (1990) propose that this region represents an uplifted part of the easternmost Cayman Rise. The region includes unmetamorphosed volcanic sequences (pyroclastics and lavas) of Late Cretaceous age. The overlying El Cobre Formation of Paleocene to late Eocene age consists of waterlain pyroclastic rocks (tuffs and breccias), with thicknesses of 4.5-6 km in the Sierra Maestra. Associated quartz diorites yield whole-rock K/Ar ages of $46-58 \mathrm{Ma}$. This structural model is consistent with results from Site 998, but the plate-tectonic configuration of the Cayman Ridge subduction zone remains in question.

The Cuban portion of the Greater Antilles arc may have been rifted, beginning in the Maastrichtian, as a result of the rollback of the Benioff zone, which split the basement between the Cayman Rise to the south and the Cuban arc, generating the Yucatan Basin (Pindell, 1993). On northern and central Cuba, however, the latest Cretaceous to Paleogene volcanic rocks are missing. This extension of the Yuca$\tan$ Basin ceased when Cuba came to rest against the Bahamas platform to the northeast during the middle Eocene ( $\sim 5 \mathrm{Ma})$. By middle 
Figure 14. Plate-tectonic setting of the Cayman Ridge volcanic arc and the Cayman Rise in the Eocene, based on the results of Site 998 drilling and from dredging in the Cayman Trough (Perfit and Heezen, 1978). Relations in southeastern Cuba and north Hispaniola are based on Pindell and Barrett (1990). The Cayman arc is attributed to a northern subduction of the leading edge of the Caribbean Plate, after collision of the Cuban arc with the Bahamas platform choked off subduction beneath the Cuban arc. Eocene (and Paleocene?) subduction beneath the Cayman arc may also have led to backarc rifting of the Yucatan Basin. The middle Eocene cessation of Cayman arc volcanism is taken as the timing of choking of the Cayman arc trench by the thicker component of the Caribbean Plate, leading to a change in the North American/Caribbean plate boundary from one of subduction to one of strike-slip, with

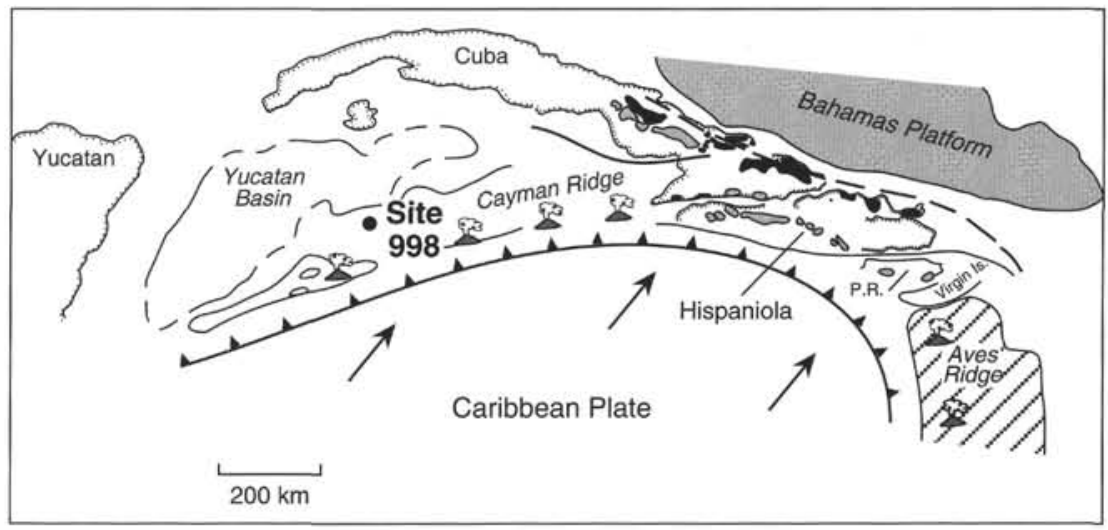
initiation of the Cayman Trough in the middle to late Eocene (Rosencrantz and Sclater, 1986).

to late Eocene times, the Cayman Rise had become a part of the North American Plate, as a new plate boundary developed to its south in the Cayman Trough. This model has implications for the age of the Cayman Rise, as its crust would have to pre-date the initiation of the rifting event (Maastrichtian-Paleocene). This is generally consistent with the age of dredged rocks from the north wall of the Cayman Fracture Zone, where Perfit and Heezen (1978) derived whole-rock radiometric ages of 59-69 Ma for granodiorites and amphibolite, suggesting a Late Cretaceous to Paleocene island-arc development of the Cayman Rise. The basement crust of the Cayman Rise could be related to the Zaza terrane in central Cuba, which includes an extensive sequence of Cabaiguan volcanic arc rocks (Pardo, 1975). These volcanics include submarine basalts and andesites, associated with volcaniclastic sediments, with the last stage of activity in the Maastrichtian.

The tectonic and petrogenetic model that best fits the evidence from Site 998, and dredging from the north wall of the Cayman Trough indicates an arc origin for the Cayman Ridge, with subaerial volcanic islands present into the Eocene (Fig. 63, "Site 998" chapter, this volume). If the Yucatan Basin was formed by backarc spreading, then the age relations indicate that its spreading occurred behind the Cayman arc, as the Cuban arc was already extinct at this time. The fundamental question regarding the Cayman arc relates to its polarity of subduction. Its relationship to the Yucatan Basin would support a north-dipping subduction zone, due to the subduction of the leading edge of the Caribbean Plate (Fig. 14). When the thicker portion (oceanic plateau) of this plate choked off the Cayman subduction zone in the middle Eocene, the plate motion along this boundary changed to one of strike-slip, with the formation of the Cayman Trough. Before the cessation of subduction and volcanic activity, the occurrence of volcaniclastic turbidites and ash fallout indicates subaerial volcanic sources on the arc. Therefore, subsidence of the Cayman Ridge and the Cayman Rise must have occurred post-middle Eocene. In general, this is consistent with the proposal of Wadge and Burke (1983) that subsidence to abyssal depths of at least the volcanic sources occurred in the Oligocene.

\section{Paleocene Volcanism}

A relatively minor episode of early Paleocene silicic explosive volcanism is recorded at Sites 999 and 1001 from 60 to $65 \mathrm{Ma}$. These tephra layers are notable for their high content of hornblende phenocrysts and therefore are probably derived from a calc-alkaline source, possibly from the early stages of Central American arc volcanism.

\section{Campanian Volcanism}

The oldest recognized episode is the mid-Campanian event recorded in Holes 1001A and 1001B just above the basement. This $\sim 76$ Ma episode, recorded by ash falls and turbidites, may represent the waning stages of oceanic plateau volcanism or a nearby arc source (see discussion below).

\section{ENVIRONMENTAL EFFECTS OF VOLCANISM}

During the climax of the Eocene and Miocene volcanic episodes, major explosive eruptive events, each one on the scale of thousands of cubic kilometers, occurred at intervals of about 20 k.y. This level of activity was sustained for several millions of years. Eruptions of this magnitude have potentially significant environmental climatic effects. The empirical evidence from historic eruptions and studies of combined climate and eruption records show that certain types of volcanic explosive eruptions can have a significant impact on climate. Research on the chemical and optical properties of volcanic plumes and long-lived volcanic veils in the stratosphere has shown, however, that sulfate aerosols are the dominant component, with an atmospheric residence time of sufficient duration to bring about a perturbation in the Earth's thermal radiation budget and cause surface cooling. Sulfate aerosols are produced from sulfur dioxide gas from the explosive eruption plume, by gas-to-particle conversion processes that are several weeks in duration. Thus, explosive eruptions that have the capacity of delivering a large mass of sulfur dioxide gas to the stratosphere are probably potential modifiers of climate. Because of its submicron size, the sulfate aerosol has a relatively long stratospheric residence time, compared to the rapid fallout of glass particles that make up the bulk of the erupted products.

The sulfur and other volatile budgets of the Central American volcanoes that produced the Eocene and Miocene tephra are unknown. Shore-based studies on glass inclusions in the tephra crystals, as well as on the Central American source regions, will help define the volatile element character of these magmas. Simply by their sheer volume, however, these eruptions must have produced very large sulfate aerosols. Most of the tephra layers that we observed in the Caribbean represent larger volumes of erupted magma than, for example, the 1815 Tambora eruption in Indonesia, which produced the largest known historic volcano-climate effect. The temporal coincidence between middle-late Eocene and early-middle Miocene explosive volcanism in Central America and major cooling steps during the Ceno- 


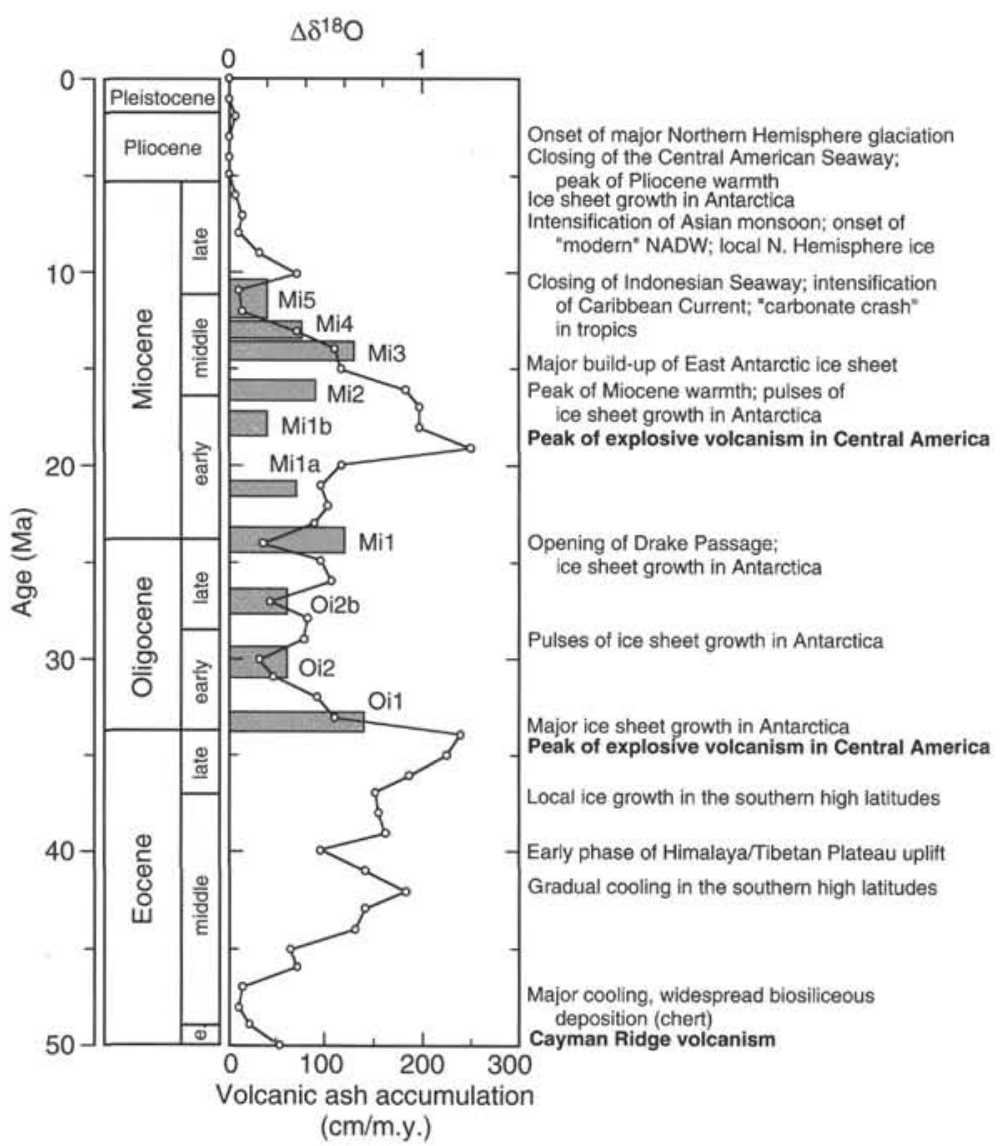

Figure 15. A 50-m.y. record of volcanic ash accumulation at Site 999 (cm/m.y.) and summary of tectonic, oceanographic, and climatic events since middle Eocene time. Major oxygenisotope enrichments in benthic $\delta^{18} \mathrm{O}$ are designated by the Oligocene ("Oi") and Miocene ("Mi") zonations of Miller et al. (1991) and Wright and Miller (1992). The relative duration of "Oi" and "Mi" events is based on the composite, smoothed data of Wright and Miller (1993). Ages of isotope events are correlated to the Berggren et al. (1995) time scale after Abreu and Haddad (in press). zoic raises the possibility of a link between volcanism and climate change (Fig. 15). We speculate that frequent injection of volcanic sulfate aerosols from the late Eocene and middle Miocene volcanic episodes may have contributed to cooling trends through nonlinear feedback mechanisms.

\section{VOLCANIC ASH ALTERATION}

The geochemistry of volcanic ash layers, interstitial waters, and sediment at most of the sites drilled on Leg 165 is interwoven in a complex manner, largely driven by the alteration of volcanic glass in the tephra layers and dispersed tephra to smectite. Chemical analyses of the ash layers show that they display a remarkable compositional range that cannot be attributed to intrinsic variation in the composition of the primary igneous material, but rather is a result of alteration. The dominant effect of alteration of glass to tri-octahedral smectite is to deplete the ash in silica and potassium and enrich it to a high degree in $\mathrm{MgO}$ and $\mathrm{Al}_{2} \mathrm{O}_{3}$. The uptake of magnesium is accompanied by enrichment of nickel in the smectite by two orders of magnitude above that in fresh rhyolitic glass, or up to concentrations of $300 \mathrm{ppm}$. This unusual enrichment of nickel must be attributed to uptake from seawater and interstitial fluids in the sediment, implying an extremely high water/rock ratio in the smectite-forming reaction. Concomitant with these enrichments is a depletion in the ash of leachable components, including $\mathrm{K}, \mathrm{Rb}$, and $\mathrm{Si}$. The loss of these constituents from the altered ash is matched in a remarkable manner by their enrichment in the interstitial pore waters, with the peak in pore-water concentration of these constituents coinciding with the peak accumulations of volcanic ash downcore. The sediment geochemistry shows that the background sediment contains a high dispersed ash component, typically on the order of $5 \%-15 \%$ of the total sediment (Fig. 16). In addition, the discrete volcanic ash layers constitute at least $2 \%$ within volcanic ash peaks; therefore, volcaniclastic sedimentation is about a tenth of the total sediment.

\section{IGNEOUS BASEMENT}

Determination of the nature and origin of the Caribbean Oceanic Plateau has been a longstanding problem in geologic studies of this region. Drilling at Site 1001 recovered an excellent succession of basaltic lavas from the northwestern region of the plateau, possibly representing the later stages of its activity at about $77 \mathrm{Ma}$. These results indicate that the lifetime of the igneous episode spans a period of at least $13 \mathrm{~m} . y$., with the oldest basalts of the oceanic plateau exposed on land around the margins of the Caribbean, dated at 88-89 Ma by ${ }^{40} \mathrm{Ar}{ }^{39} \mathrm{Ar}$ methods (Duncan et al., 1994). The presence of volcaniclastic turbidites of basaltic composition and coexisting ash layers within the Campanian limestone at Site 1001 may indicate that the late stages of volcanic activity on the Caribbean Oceanic Plateau may in fact be even later, or at about $74 \mathrm{Ma}$, giving a lifetime of the hotspot event on the order of 15 m.y.

The basalts in the succession at Site 1001 were formed entirely during submarine eruptions, and the succession represents two distinctly different effusive basalt types: pillow lavas with multiple flow units, and thicker and more massive sheet flows. The latter are particularly important in that this flow type may have been misidentified 

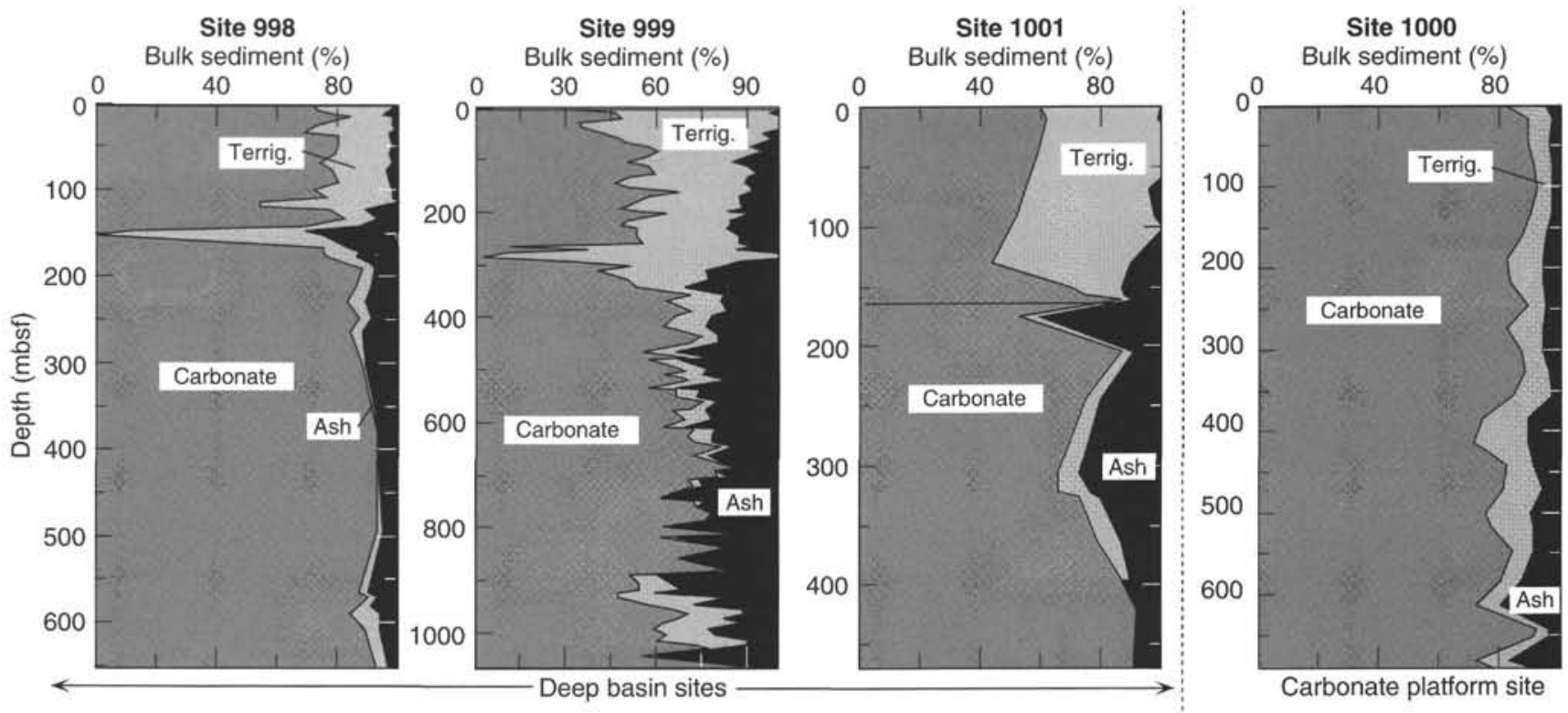

Figure 16. Dispersed ash and terrigenous components in sediments at Sites 998, 999, 1000, and 1001 calculated on the basis of geochemical normative models.

elsewhere on the ocean floor, particularly on oceanic plateaus, as sill intrusions and often referred to as "dolerites." The excellent core recovery of the sediment/basalt lava contact in two holes at Site 1001, and of the brecciated upper parts of the sheet lava flows shows that flows of this type have a characteristic structure and petrography that consists of a massive, columnar jointed and relatively coarse-grained flow interior, subophitic or "doleritic" in texture, overlain by and gradational with a basaltic hyaloclastite breccia and glassy lapilli. The overlying hyaloclastite breccia and coarse lapilli, which may be several meters thick, includes veins or apophyses of very fine-grained basalt that stem from the underlying massive facies of the flow. Sheet flows of this type may represent eruptive events of very high mass eruption rates, judging from their thickness and lithology. A high magma supply rate will generate a widespread lava sheet, but quenching at the top surface of the flow against seawater results in the production of a hyaloclastite breccia boundary layer. The mobility and lateral extent of such flows, therefore, may be very high, as they are not subject to the same process of quenching that affects flows of low mass eruption rates, in which the rate of quenching is high in comparison with the mass eruption rate and results in pillow lava formation.

The hyaloclastite breccia and lapilli that make up the boundary layer between the sheet flow and overlying seawater will be a region subjected to vigorous thermal convection. The transfer of heat out of the lava by this process may also result in extensive mineralization, and we suggest that the strikingly beautiful assemblage of calcite, gypsum, and other minerals filling vugs in the hyaloclastite breccia may be of this origin (Fig. 44, "Site 1001" chapter, this volume). Widespread and smooth reflectors on the Caribbean seafloor, associated with the B" seismic reflector, may owe their character to this type of sheet flow. Furthermore, the impedance contrasts expected from breccia and hyaloclastite tops of sheet flows may create the reflections observed within multichannel seismic profiles in the upper part of the Caribbean Oceanic Plateau (Diebold et al., 1995a, 1995b).

Sheet flows are likely to be more characteristic of hot-spot activity, as compared to the steady-state process of low mass-eruption rate during accretion of magma in the rifts of mid-ocean ridges. At a modern hot spot such as Iceland, basaltic sheet flows on the order of tens of cubic kilometers are extruded at very high mass eruption rates and can cover great distances during subglacial and subaerial events. By analogy, we could expect Caribbean sheet flows to extend hundreds of kilometers from their source, given a favorable topography of the seafloor and a high mass eruption rate. Sheet flows are more likely, however, to pass laterally into pillow lavas at their margins, where the flow rate diminishes and where quenching overcomes the advance of the fluid interior mass, resulting in the development of discrete pillows.

The basalts recovered at Site 1001 also exhibit interesting chemical features. They are of two distinct compositional types, representing the lower (more primitive) and upper part of the succession. The lower part of the succession is characterized by lavas with higher $\mathrm{MgO}$ and $\mathrm{FeO}$, whereas the upper lavas are enriched in $\mathrm{Al}_{2} \mathrm{O}_{3}$ and $\mathrm{CaO}$. Shipboard results show that these differences are not simply related to shallow fractionation processes, but further understanding of the basalt chemical trends will require additional shore-based work. Preliminary data indicate that the basalts from Site 1001 are very depleted in incompatible trace elements, much more so than oceanisland basalts. Large ion-lithophile and high-field-strength elements for many samples are equally, or more, depleted than typical $\mathrm{N}$ MORB (Fig. 17). Subsolidus alteration has had a minor effect on the elemental chemistry of most samples. Some show minor enrichments in $\mathrm{Rb}$ compared to other incompatible elements, which may be attributed to the effects of seawater alteration. Basalts recovered from the basement of oceanic plateaus such as the Ontong Java Plateau are typically slightly more enriched in incompatible elements than the Caribbean basalts recovered at Site 1001 (Fig. 17). This difference is also apparent on a $\mathrm{Zr}$ vs. Nb plot (Fig. 18), which shows the more MORB-like character of the Caribbean basalts, manifest in their high $\mathrm{Zr} / \mathrm{Nb}(\mathrm{N}-\mathrm{MORB}>25)$. The fairly restricted range of $\mathrm{Mg}$ numbers indicates limited fractionation, and so the spread in $\mathrm{Zr} / \mathrm{Nb}$ may be a source feature. In general, the trace element characteristics of these basalts are transitional between MORB and ocean-island basalt volcanism, which may reflect a combination of depleted and more enriched source components, as advocated for Ontong Java Plateau basalts (Mahoney, 1987). Such models will be more rigorously tested by detailed, shore-based trace element and isotopic work.

Carbonate sediment lenses within the basalts at Site 1001 contain a benthic foraminiferal assemblage that may indicate upper bathyal water depths. In addition, the vesicularity of the basalts suggests that water depths were considerably lower than those typical at the mid- 


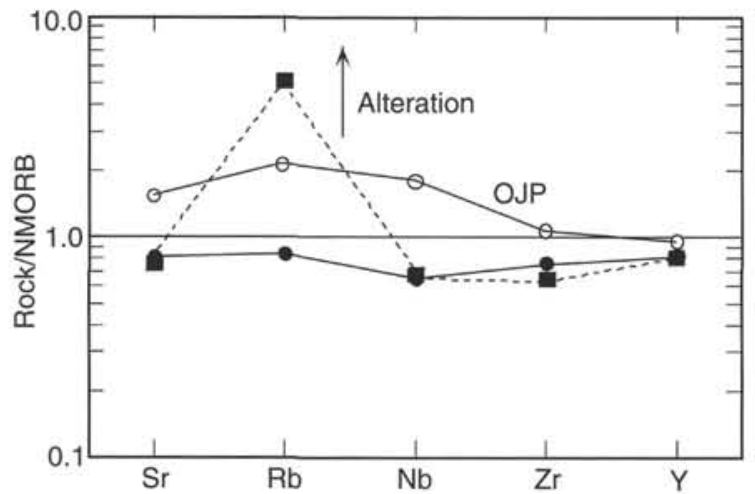

Figure 17. N-MORB normalized trace element abundances of incompatible elements for selected Site 1001 tholeiite basalts. A typical Ontong Java Plateau (OJP) tholeiite is shown for comparison (data from Mahoney et al., 1993). Arrow indicates probable Rb enrichment caused by alteration.

ocean ridge, perhaps in the 1- to 2-km range. Combined with paleontological evidence from the overlying Campanian limestone, we take this to indicate that the Caribbean Oceanic Plateau at Site 1001 was relatively shallow at the time of volcanism and then experienced progressive subsidence during the Campanian, after the cessation of volcanic activity. This observation is consistent with the general relationship of lithospheric subsidence as a function of age.

The presence of several thick volcaniclastic turbidites and andesitic volcanic ash layers of intermediate composition at Site 1001, about 5 to $10 \mathrm{~m}$ above the basaltic basement, poses an interesting problem. The basaltic turbidites contain benthic foraminifer and oxidized basalt fragments, indicating a relatively shallow-water source, possibly from emergent volcanic islands on the oceanic plateau or from shallow seamounts. Further geochemical studies are required to establish whether these volcaniclastic layers have a chemical affinity with the Caribbean Oceanic Plateau basalts. The associated volcanic ash layers of intermediate composition $\left(\sim 59 \%-63 \% \mathrm{SiO}_{2}\right)$ have chemical characteristics that are unique when compared with other Caribbean tephra. They may represent relatively local explosive eruptions of intermediate to silicic magmas from central volcanoes on the Caribbean Oceanic Plateau, although an alternate origin from circum-Caribbean arc complexes cannot be ruled out at this stage.

The past locations and motions of most plates on the Earth's surface are now relatively well known, although the Caribbean Plate is still an enigma with two competing hypotheses for its origin. In one, the Caribbean Plate formed, presumably by means of seafloor spreading, between North and South America as the two continents separated during the Late Cretaceous and Tertiary. In the other, the Caribbean Plate formed about $90 \mathrm{Ma}$ in the Pacific Ocean as a hotspot-generated oceanic plateau, probably associated with the initial rupture of the plume head of the Galapagos hot spot through the lithosphere of the Farallon Plate (Duncan and Hargraves, 1984). Unlike the surrounding Farallon Plate on which it formed, the thick, buoyant Caribbean Oceanic Plateau would have resisted being subducted. These two models provide testable predictions as to the paleolatitudes, paleobathymetry, and geochemistry expected for the Caribbean basement.

Initial results suggest that the Caribbean Plate probably was located near the paleoequator from the Late Cretaceous to at least the middle Eocene, as suggested by the very shallow paleomagnetic inclinations obtained from the basalt and overlying sediments at Site 1001 and from ash layers at Site 999. Furthermore, the vesicularity of the basalt and the occurrence of possible upper bathyal benthic foraminifers from limestone lenses within the basalt at Site 1001 may indicate a shallow-water environment for at least part of the Caribbean

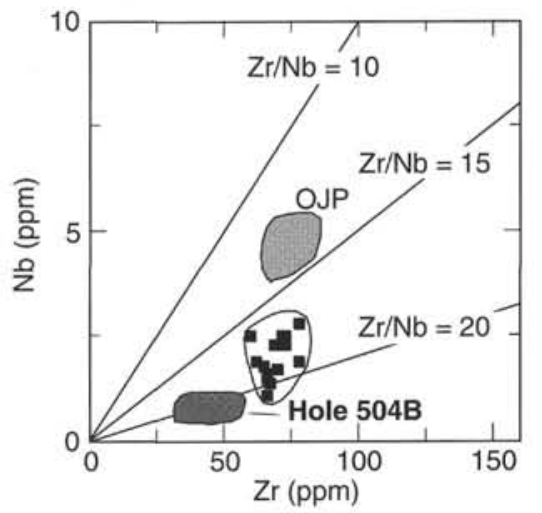

Figure 18. $\mathrm{Zr}$ vs. $\mathrm{Nb}$ for Site 1001 tholeiite basalts. Basalts from Hole 504B in the Pacific Ocean and the Ontong Java Plateau are shown for comparison.

plateau in the middle Campanian. Given also that the geochemical affinities of the basalt indicate a source that may represent a mixture of MORB and plume-derived components, a hot-spot origin for the Caribbean Plate appears very appealing.

\section{CRETACEOUS/TERTIARY BOUNDARY}

Following the discovery of an iridium anomaly at the $\mathrm{K} / \mathrm{T}$ boundary, the bolide impact hypothesis has become central to the debate about the cause of the global extinctions that define this important divide in Earth history (Alvarez et al., 1980). The discovery of both shocked quartz (Hildebrand and Boynton, 1990) and impact glass spherules or tektites (Sigurdsson et al., 1991) in the 50-cm to 1-mthick $\mathrm{K} / \mathrm{T}$ boundary deposit at Beloc in Haiti provide direct evidence for a major impact at this time. Studies of the $\mathrm{K} / \mathrm{T}$ boundary in the Caribbean region are of particular relevance because of the proximity to the Chicxulub crater on the northern end of the Yucatan Peninsula. The location of sites drilled during Leg 165 was influenced, in part, by our desire to recover $\mathrm{K} / \mathrm{T}$ boundary sections for further study of the impact ejecta and of the effects of the impact on biota, as recorded in the earliest Tertiary sediments of the Caribbean. Thus, we chose Site 998 because we felt that proximal $\mathrm{K} / \mathrm{T}$ boundary deposits might be recovered there. Owing to technical problems and time constraints, however, drilling at this site did not extend to the proposed depth of the $\mathrm{K} / \mathrm{T}$ boundary.

The K/T boundary deposit was recovered in three holes on Leg 165. In Hole 999B on the Kogi Rise in the Colombian Basin, the boundary was recovered in Section 165-999B-60R-1 at a depth of $1050 \mathrm{mbsf}$. The boundary deposit recovered is only $2 \mathrm{~cm}$ thick, but Formation MicroScanner (FMS) downhole logging indicates that the in situ thickness of the boundary deposit here is on the order of $10 \mathrm{~cm}$. This is lower than expected, given the observed thickness in Haiti and the paleogeographic location of the Kogi Rise with respect to the Chicxulub crater at the time of impact. The anomalous thickness of the boundary deposit at Site 999 may be an indication of an oblique impact. A general asymmetry is apparent in the structure of the Chicxulub impact crater, but whether this is a primary feature or the result of post-impact tectonic modification is unclear. The Bouger gravity data show a $100-\mathrm{km}$ diameter, horseshoe-shaped structure, or inner ring, that is partially open to the northwest (Pilkington et al., 1994). A northeast-trending lineament also truncates the approximately 180 - to $200-\mathrm{km}$ diameter structure along its northern flank. The break in the circularity of the gravity anomaly and in the aeromagnetic data in the northwest portion of the structure is a major unexplained feature. The asymmetry may be the result of preexisting anomalies in the Yucatan crust, such as an older crustal rift system, 
or post-impact magmatic intrusion; alternatively, it may be caused by an oblique impact, as proposed by P.H. Schultz (pers. comm., 1996; Schultz and D'Hondt, 1995).

The cratering process and the ejecta dispersal pattern change systematically with the impact angle (Schultz and Gault, 1982, 1990). The most probable impact angle is $45^{\circ}$, but there are fundamental differences between oblique and vertical impacts, particularly in the partitioning of the impact energy between the atmosphere, the nearsurface, and the deeper crust. In oblique impacts, a much larger fraction of the initial kinetic energy is partitioned into the near-surface and surrounding environment rather than the deep target, resulting in greater vaporization of easily volatilized target materials. Thus, oblique impacts can significantly enhance the environmental response by increasing the energy fraction that is partitioned into the nearsurface, the atmosphere, and the vapor cloud expansion (Schultz and Gault, 1990). An oblique impact also produces a marked asymmetry in the distribution of the ejecta deposit, with high down-range and lateral ejection of debris and minimal ejecta deposition in the up-range direction. Such a pattern would be consistent with the low observed boundary deposit thickness at Site 999 on the Kogi Rise, which would imply that the trajectory of the bolide was from the southeast of Chicxulub.

At Site 1001, the K/T boundary was recovered twice (in Holes $1001 \mathrm{~A}$ and 1001B), only a few tens of meters apart. In Hole 1001A, the boundary was recovered (at $352.7 \mathrm{mbsf}$ ) in the core catcher of Core 165-1001A-38R unfortunately, and hence the recovered section is somewhat disturbed. The recovered boundary deposit in this hole is $8.5 \mathrm{~cm}$, whereas the FMS downhole log indicates that a low resistivity layer, which most likely corresponds to the boundary deposit, is on the order of $30 \mathrm{~cm}$ thick (Fig. 19). A detailed comparison between the magnetic susceptibility record of cores from both of these holes with the downcore magnetic susceptibility data of Hole 1001A (Fig. 54, "Physical Properties" section, "Site 1001" chapter, this volume) indicates that the thickness of the missing boundary section is on the order of $15-20 \mathrm{~cm}$. The missing material is probably in the lower part of the deposit, as the upper claystone is well preserved and is strongly correlated between the two holes (Fig. 69, "Site 1001" chapter, this volume). Thus, the total inferred thickness of about 25 $\mathrm{cm}$ for the $\mathrm{K} / \mathrm{T}$ boundary deposit at Site 1001 is significantly thinner than the $0.5-$ to $1-\mathrm{m}$ deposit exposed on Haiti, $350 \mathrm{~km}$ to the northnortheast (Sigurdsson et al., 1991).

The boundary was also recovered at a depth of $352.9 \mathrm{mbsf}$ in Hole 1001B. The composite K/T boundary succession in these two adjacent holes can be divided into several units. Above the boundary is a distinctive, highly indurated, white to light gray limestone band, 2 to $4 \mathrm{~cm}$ thick (Layer A), from the lowermost combined early Paleocene Zone $\mathrm{P} 0 / \mathrm{P} \alpha$. A white limestone with exactly the same appearance was also recovered on top of the boundary clay at Site 999 in the Colombian Basin. It consists of fine-grained carbonate with a sparse planktonic foraminifer fauna composed largely of tiny Guembelitria cretacea. The white limestone band is overlain by calcareous chalk and calcareous mixed sediment, with a much higher clay content. It appears, therefore, that a brief period of nearly pure carbonate deposition and a very low input of terrigenous clay characterized the Caribbean sedimentation immediately following the $\mathrm{K} / \mathrm{T}$ boundary impact. The significance of this sedimentary unit and its relationship to the boundary event is unclear at this time.

The uppermost part of the boundary deposit, directly below the white limestone, is a 1 - to 3.5 -cm-thick medium gray claystone (Layer B), consisting of a mixture of carbonate sediment and clay. It contains common grains of quartz and other mineral grains, including a number of 100 - to $150-\mu \mathrm{m}$ diameter grains of quartz with the planar deformation features that are characteristic of the type of shock metamorphism that crustal rocks are subject to during hypervelocity bolide impacts (Fig. 68, "Site 1001" chapter, this volume). No shipboard geochemical studies have been conducted on this unit, but we anticipate that it contains the iridium anomaly (this will be evaluated by shore-based research). The upper contact of Layer B with the Paleocene white limestone is quite sharp, and the top of the brownish claystone has faint laminations, whereas the lower boundary of the unit is gradational.

At Site 1001, the lower part of the boundary deposit is composed of three layers (C, D, and E) that are entirely dominated by smectite, with a total recovered thickness of the smectite layer of about $4-5 \mathrm{~cm}$ (Fig. 19). We suspect that the unrecovered portion of the $\mathrm{K} / \mathrm{T}$ boundary at Site 1001 is most likely the 20 - to 25 -cm-thick lower part of the smectite layer. The uppermost part of the smectite layer (Layer C) is a greenish gray, massive, and consolidated layer, containing darker greenish gray 1 - to 2 -mm diameter smooth spherules. These spherical bodies are virtually the sole component of the unit, which contains a minor amount of carbonate. These particles have the same morphology as impact glass spherules found in the lower part of the $\mathrm{K} / \mathrm{T}$ boundary deposit in Haiti, where they range up to $8 \mathrm{~mm}$ in diameter. We therefore interpret the smectite spherules at Site 1001 as alteration products of impact glass or tektites, which were deposited as a normally graded tektite fallout layer. The high degree of induration of Layer C may account for the moderate to high resistivity of this level in the FMS image, in contrast to the low-resistivity bands of Layers B and D above and below it (Fig. 19).

Layer D is also smectite-rich and gradational with Layer C above, but much less indurated and more shaley in the lower part. Layer E is similarly a shaley smectite, and we consider it likely that the shaley aspect of these units may be caused by drilling disturbance of the soft and easily deformed smectite. Layers D and $\mathrm{E}$ are notably darker in color than Layer $\mathrm{C}$, however, and this may reflect a significant difference in composition.

The core drilled immediately below the boundary (Section 165$1001 \mathrm{~A}-39 \mathrm{R}-1)$ recovered four small $(3-4 \mathrm{~cm})$ pieces of smectite that encloses up to 6-mm angular clasts of limestone and other sedimentary rocks. These poorly sorted pieces are of two types, with a dark greenish gray or a brown smectite matrix, and they have the appearance of a polymict micro-breccia. We cannot establish the exact location of the unit represented by these micro-breccia pieces, but they are clearly from the smectite boundary layer. They may represent the "missing" portion of the $\mathrm{K} / \mathrm{T}$ boundary deposit, but further shorebased work on their lithology and composition will be needed to clarify this issue. We point out that the Haiti deposit, some $350 \mathrm{~km}$ to the north of Site 1001, contains an impact glass-rich gravity current deposit, 20 to $40 \mathrm{~cm}$ thick, that is sandwiched between the basal impact glass fallout layer and the overlying boundary clay layer with the iridium anomaly. By analogy with the Haiti section, we would expect that a poorly sorted layer, such as may be represented by the pieces of micro-breccia, should also occur at Site 1001 between the uppermost claystone and the impact spherule layer at the base.

\section{CARIBBEAN SEDIMENT CHEMISTRY}

\section{Quantifying Dispersed Ash and Terrigenous Matter}

During Leg 165, an ambitious analytical sediment chemistry program was initiated, resulting in a total of 193 samples being analyzed for five major elements ( $\mathrm{Fe}, \mathrm{Mn}, \mathrm{Ti}, \mathrm{P}$, and $\mathrm{Ca}$ ) and 11 trace elements $(\mathrm{Nb}, \mathrm{Zr}, \mathrm{Y}, \mathrm{Sr}, \mathrm{Rb}, \mathrm{Zn}, \mathrm{Cu}, \mathrm{Ni}, \mathrm{Cr}, \mathrm{V}$, and $\mathrm{Ba}$ ) by X-ray fluorescence spectrometry (XRF) of pressed powder samples. Quality control and appropriate calibrations were achieved by using high-carbonate sedimentary international and in-house reference standards. Combined with the 69 ashes and 14 basalts that were also analyzed on this leg using the conventional ODP preparatory scheme (i.e., fused glasses and pressed powders), the rapid generation of these research-grade, high-quality data on board reflects the outstanding commitment and energy of the ODP technical staff.

The resulting bulk sediment chemistry data was used primarily during the cruise to quantify the absolute amounts of terrigenous material and dispersed ash (as opposed to discrete ash layers) through 


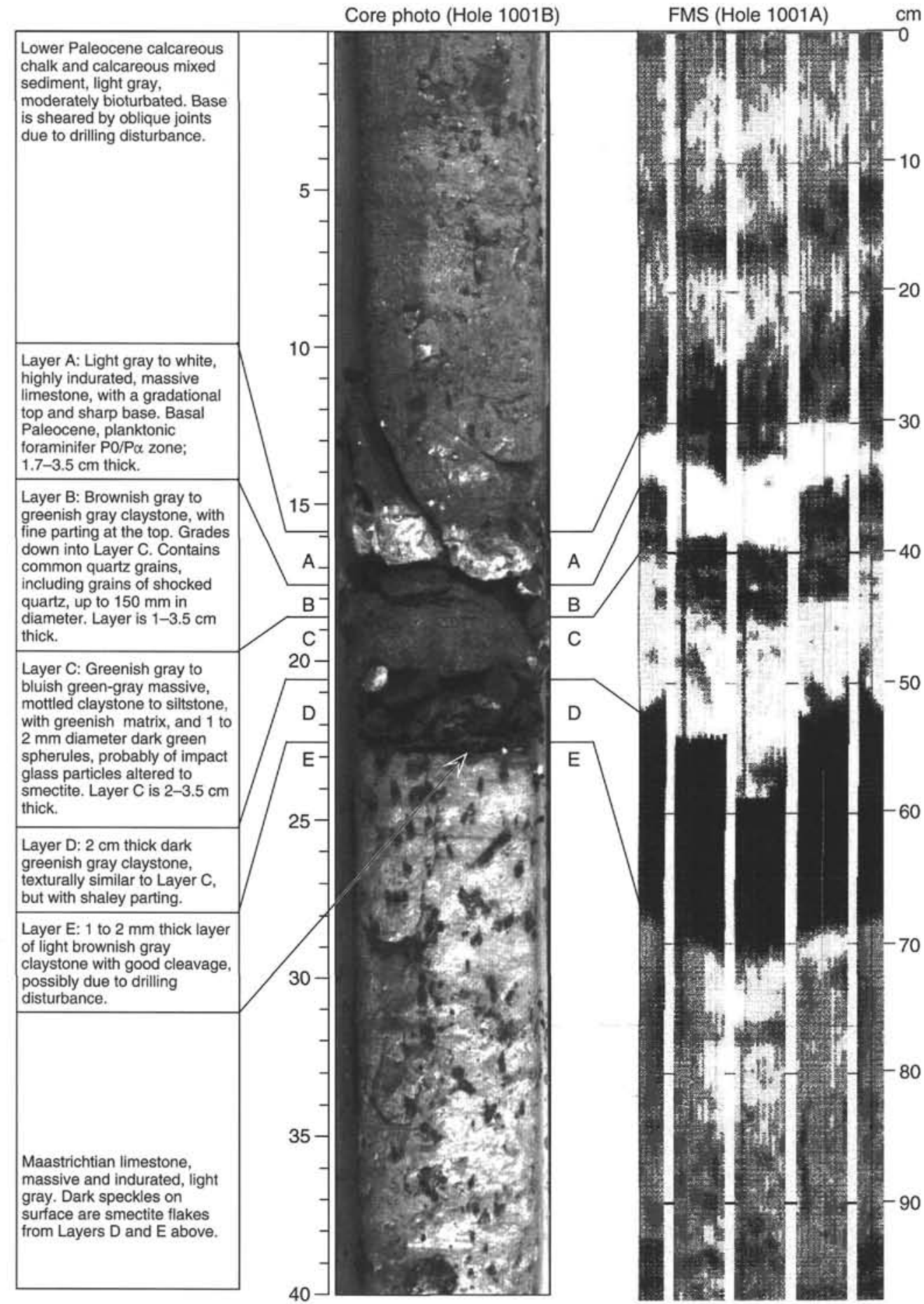

Figure 19. K/T boundary at Site 1001 on the lower Nicaraguan Rise. On the left is a lithostratigraphic description of the recovered boundary deposit in Section 165-1001B-18R-5. In the center is a core photograph of unsplit Section 165-1001B-18R-5, 15-55 cm. Note that the dark specks on the surface of the upper Maastrichtian limestone are smectite particles that have been eroded from the basal part of the boundary deposit during drilling. On the right is the Formation MicroScanner (FMS) downhole log of the K/T boundary interval. The FMS record displays a high-resistivity band (bright to white), which we interpret to reflect the hard limestone immediately above the $\mathrm{K} / \mathrm{T}$ boundary. It is underlain by a 30 -cm-wide zone of low to very low (dark) resistivity, which we interpret as the $\mathrm{K} / \mathrm{T}$ boundary deposit. Interpretations of the downhole magnetic susceptibility logging data of Hole 1001A (see "Physical Properties" section, "Site 1001" chapter, this volume) and comparison with the magnetic susceptibility log of the recovered cores are also consistent with a 20- to 30-cm-thick, in situ boundary deposit at this site. Thus, approximately only a third of the deposit was recovered by drilling. 
the sediment column at each site. Quantifying the amount of these components is particularly important in documenting the tectonic changes that drive variability in terrigenous and volcanic ash supply to the Caribbean Sea, constraining diagenetic reactions, evaluating the pore-water profiles, and defining the sedimentologic nature of the recovered sequence. Sediment chemistry studies have identified the sediment intervals through which shale-type material (i.e., detrital terrigenous matter) is the source of the dominant clay type, and those intervals in which the clay is composed primarily of altered volcanic ash. This differentiation is critical to many of the cruise objectives because distinguishing the true terrigenous component allows assessment of tectonically driven changes in continental erosion at different locations throughout the Caribbean Sea, while quantifying the true dispersed ash component allows assessment of the arc-related volcanic activity and provides further support of the megascopic ash layer data.

An overview of the results is shown in Figure 16, which partitions the bulk sediment at Sites 998, 999, 1000, and 1001 into the three components of calcium carbonate, terrigenous material, and dispersed ash. Calcium carbonate is measured coulometrically, terrigenous material is calculated from the sediment chemistry, and the dispersed ash is calculated either by the difference or as part of a normative model (details are provided in the respective site chapters). Although shore-based calculations of the mass accumulation rates of the respective components will further test the following observations, the shipboard program clearly identifies several major depositional regimes.

1. An uppermost regime, typically 100 to $250 \mathrm{~m}$ thick, is composed almost exclusively of calcium carbonate and terrigenous matter (i.e., with minimal dispersed ash), and is best documented at the deep basinal Sites 998, 999, and 1001. Within this regime, subtle variations in terrigenous detrital provenance are evident from elemental ratios of refractory elements such as $\mathrm{Zr}, \mathrm{Ti}, \mathrm{Cr}$, and $\mathrm{Zn}$; these provenance changes most likely reflect the waxing and waning of both depositional and erosional processes, such as changes in Andean uplift and construction of nearby submarine fans (e.g., the Magdelena Fan near Site 999).

2. The middle Miocene carbonate minimum, described at length above, is most notably observed at Sites 998 and 999 . The sediment chemistry through this interval indicates that most of the concomitant increase in clay is the result of an increase in the relative proportion of the detrital terrigenous component, and that there is not an increase in ash deposition through this interval.

3. An intermediate-depth regime, located below the middle Miocene carbonate minimum, is composed of $<10 \%$ terrigenous matter and an increasing percentage with depth of dispersed ash. This regime, which varies in thickness from site to site but is consistently present, will be especially targeted during post-cruise study as it represents the initiation of significant terrigenous input to the Caribbean Sea, and thus will yield important information regarding the tectonic evolution of the Central American and South American highlands.

4. This is a deep regime, composed of very high amounts of calcium carbonate and lower absolute amounts of dispersed ash and terrigenous matter, but with high relative amounts of dispersed ash, which correlates well with the increasing frequency and thickness of discrete ash layers. Comparing the precise timing of accumulation rate changes of the dispersed ash component to the accumulation of the discrete ash layers will better resolve the volcano-sedimentary processes responsible for transporting the dispersed ash from the landmasses to the deep sea. For example, although it is clear that the large eruptions are preferentially recorded in the distal deep sea, the dispersed ash may reflect the continental erosion of the massive ignimbrite deposits that also resulted from the same large eruptions. Mass balance calculations of the combined dispersed and discrete ash components of the sediment column will provide important constraints on the magnitudes of the volcanic episodes.

\section{PORE-WATER CHEMISTRY}

Leg 165 has afforded a unique opportunity to investigate organic and inorganic sedimentary geochemistry across a wide gradient of compositional variation and range of chemical pathways. The solid fractions at Sites $998,999,1000$, and 1001 revealed varying proportions of reactive carbonate species, labile ash components occurring in discrete layers and as a dispersed component, and detrital fluxes that derive from continental weathering. The relative proportions and reactivities of these end members strongly dictate the character of the diagenetic profiles observed during the course of Leg 165 . In addition, alteration of the well-characterized basaltic basement at Site 1001 has provided a strong signal that is manifested in many of the dissolved components.

With the exception of Site 1002, the sediments encountered during Leg 165 were uniformly deficient in organic carbon. Consequently, rates of anaerobic respiration were generally low and the concomitant redox cycling was dominated by suboxic diagenesis with subordinate levels of bacterial sulfate reduction and methanogenesis. Site 1000 provided a notable exception. At this site, although the sediment is comparatively depleted in reactive organic phases, externally derived thermogenic hydrocarbons drive enhanced levels of redox diagenesis at great depths below the seafloor. The entrapment of these volatiles corresponds with a permeability seal defined by the Miocene carbonate minimum and with a dramatic downcore transition from chalks to well-lithified limestones. The latter has been attributed to increases in alkalinity associated with microbial degradation of hydrocarbons. Increased alkalinity facilitates the precipitation of carbonate cements and overprints pore-water profiles that are otherwise dominated by carbonate dissolution and reprecipitation reactions in the aragonite-rich host sediment (Fig. 20).

As detailed elsewhere, recognition and quantification of the previously unconstrained large volumes and frequencies of Eocene and Miocene silicic ash within the Caribbean basin are one of the major contributions of Leg 165. The presence of the ubiquitous ashes is recorded to varying extents within the pore-water profiles of Leg 165.

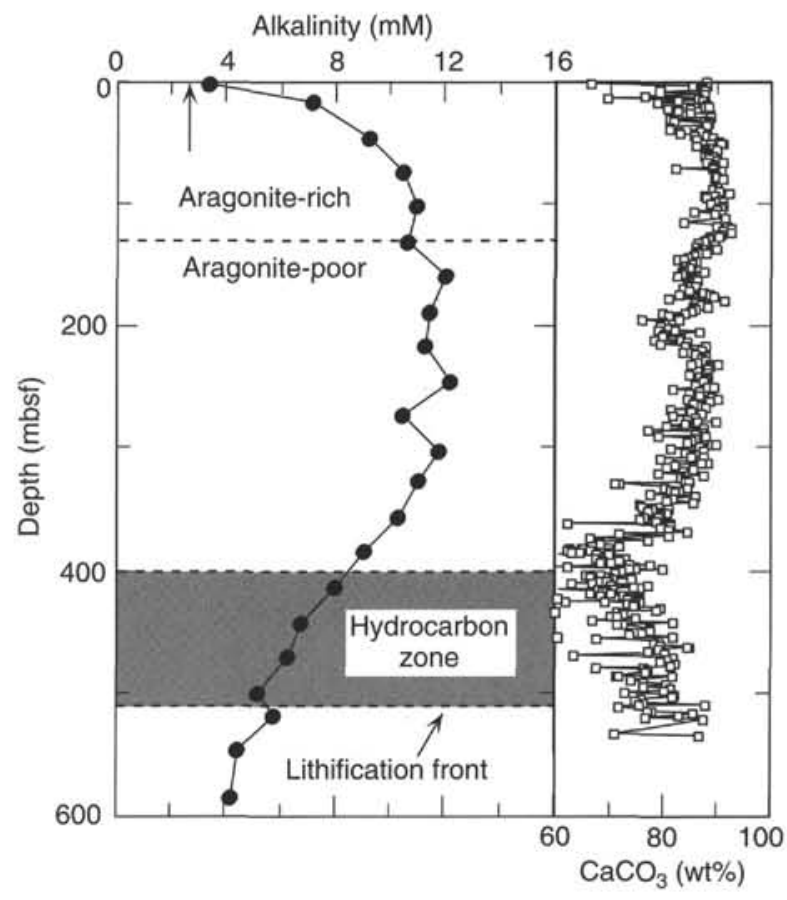

Figure 20. Alkalinity in Hole 1000A interstitial waters compared to bulk calcium carbonate contents of sediment. Arrow indicates mean ocean-bottomwater sulfate composition. 


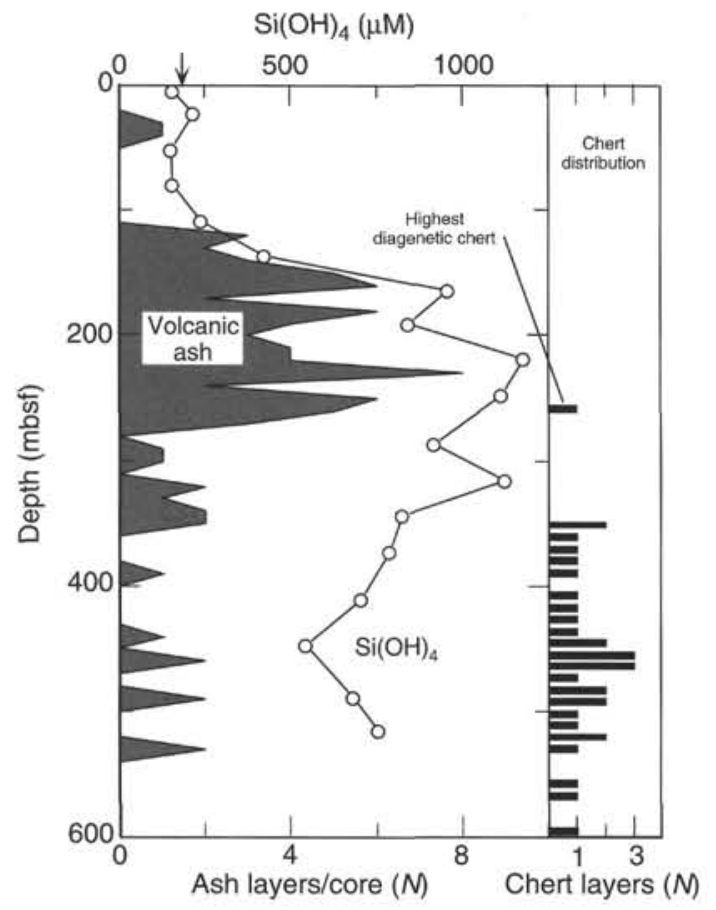

Figure 21. Depth profile of silica in Site 998 interstitial waters. Frequency of chert layers with depth indicated as histogram. Ash distribution also shown.

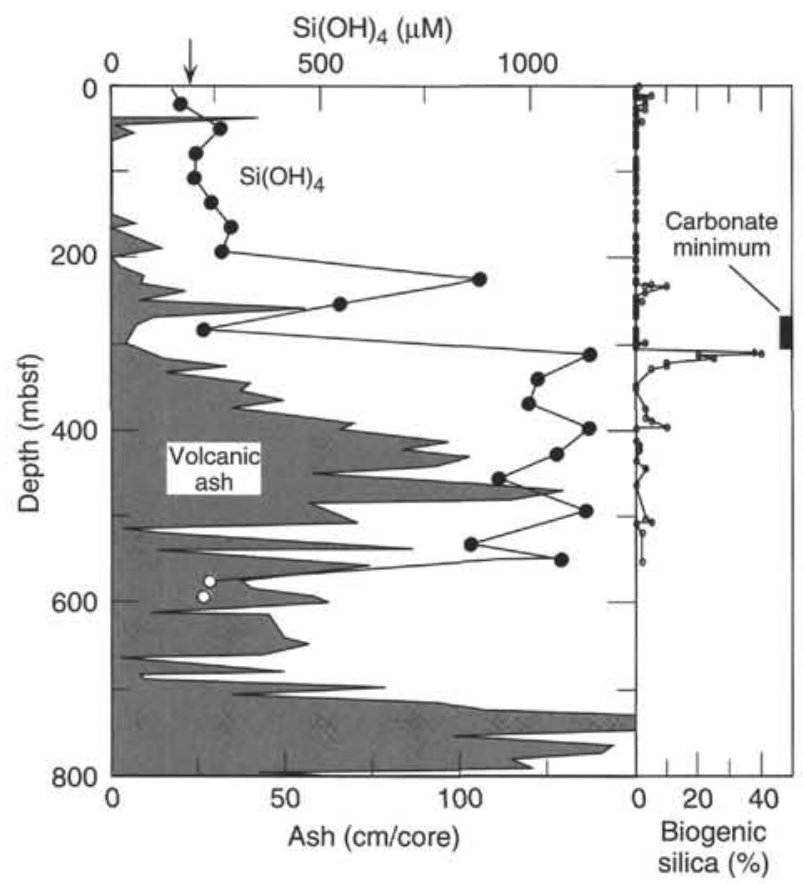

Figure 22. Depth profile of silica in Site 999 interstitial waters. The transition from open to closed or closed to open symbols on a single profile differentiates between Holes 999A and 999B. Quantification of the ash component is presented as the percentage of dispersed ash in the sediment column at a given depth to permit evaluation of the effect of ash on pore-water chemistry. Arrows indicate mean ocean-bottom-water composition. Also plotted is the distribution of biogenic opal, as determined from smear-slide analyses.

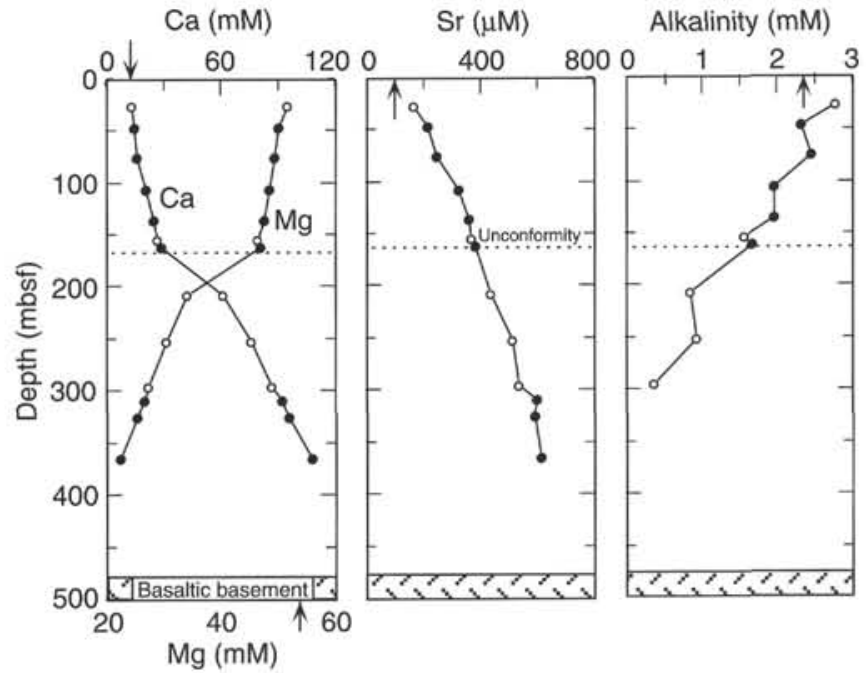

Figure 23. Depth profiles of $\mathrm{Ca}, \mathrm{Mg}, \mathrm{Sr}$, and alkalinity in Site 1001 interstitial waters. Solid symbols $=$ Hole 1001A, open symbols $=$ Hole 1001B Dashed line indicates the level of the erosional unconformity. Depth to basaltic basement indicated. Arrows indicate mean ocean-bottom-water composition.

At Site 998, the alteration of ashes and associated glasses, as recorded in the frequency of discrete layers, exerts a strong control on the downcore distributions of a range of dissolved species (e.g., silica and cations such as $\mathrm{Mg}, \mathrm{Rb}$, and $\mathrm{K}$ ). Important reactions include alteration to $\mathrm{Mg}$-rich smectite and reverse weathering pathways involving the precipitation of clay minerals and zeolites. These relationships are recorded by dissolved silica, which also indicates consumption by chert precipitation (Fig. 21).

Similar ash-related signals are recorded in the pore-water profiles of Site 999. Unlike Site 998, however, ash-layer frequency is only a limited proxy for the extent of ash alteration; distributions of dispersed ash exert a stronger influence of dissolved species such as $\mathrm{Rb}$, $\mathrm{K}$, and $\mathrm{Li}$. Furthermore, concentrations of dissolved silica, which closely parallel estimates of ash abundance, show a striking correspondence between pore-water enrichments and distributions of siliceous microfossils (Fig. 22). This relationship is thought to record enhanced preservation of biogenic silica within ash-rich zones as a consequence of silica buffering during alteration. Despite diffusional smoothing, the pore-water signatures of a local scale process (ash alteration) are retained at Site 999.

The pore waters analyzed throughout Leg 165, and indeed throughout much of the deep ocean, show an antithetic relationship between concentrations of $\mathrm{Ca}$ and $\mathrm{Mg}$. Although multiple factors may contribute to this commonly observed relationship, the sediments at Site 1001 reveal an unequivocal link to the alteration of the underlying basaltic basement. Calcium is released during the alteration of calcic plagioclase, with corresponding $\mathrm{Mg}$ uptake during precipitation of $\mathrm{Mg}$-rich smectite. The dramatic increase in porewater $\mathrm{Ca}$ at Site 1001 is of sufficiently large magnitude to account for a roughly $10 \%$ increase in salinity. The general relationships between $\mathrm{Ca}, \mathrm{Sr}$, and alkalinity (Fig. 23) argue for a Ca source that is decoupled from the calcium carbonate system and, when viewed in the context of all available data (e.g., $\mathrm{K}, \mathrm{Rb}$, and $\mathrm{Na}$ ), suggest a strong signal from alteration of the proximal basaltic basement.

These highlights emphasize the value of addressing the aqueous geochemical aspects of deep-marine sediments within a well-constrained, integrated context. By defining the system carefully in terms of both solid and dissolved species of varying concentrations and reactivities, the downcore distributions of a wide range of interstitial components can be better understood with regard to the rates and styles of sequestration and release. Ultimately, a better mechanistic 
understanding of these processes and the extents to which they have varied spatially and temporally will bear profoundly on the global mass balances for a wide range of major and minor seawater components. For example, planned studies will address the extent to which the alteration of Eocene ashes, which are now known to represent a major component of the Cenozoic stratigraphic section in the Caribbean, may affect levels of oceanic $\mathrm{Si}$ and ultimately may catalyze the accumulation of the vast amounts of chert that abound in the Eocene marine record. Further investigations will address possible overprints associated with fluids derived from deep sources, including the basement. This phenomenon has been invoked to explain $\mathrm{S}^{-}$and $\mathrm{Ni}^{-}$enrichments observed in ash-rich sediments of Leg 165.

Finally, the multiple piston cores recovered at Site 1002 in the Cariaco Basin, the world's second largest anoxic basin, provide an unprecedented opportunity to study redox chemistry at extremely high temporal resolution. By applying a sampling and analytical approach relatively unexplored within the context of the Ocean Drilling Program, we have been able to characterize a broad range of microbially mediated processes and their sedimentary signatures within the uppermost Holocene layers of the basin. Longer term, high-resolution studies will speak to geochemical trends across temporal gradients in depositional redox, biologic productivity, terrestrial inputs, and climatic and oceanic variability.

\section{REFERENCES}

Abreu, V.S., and Haddad, G.A., in press. Glacioeustatic fluctuations: the mechanism linking stable isotope events and sequence stratigraphy from the early Oligocene to middle Miocene. Spec. Publ.-Soc. Econ. Paleontol. Mineral.

Alvarez, L.W., Alvarez, W., Asaro, F., and Michel, H.V., 1980. Extraterrestrial cause for the Cretaceous/Tertiary extinction. Science, 208:10951108.

Atwater, T., 1989. Plate tectonic history of the northeast Pacific and western North America. In Winterer, E.L., Hussong, D.M., and Decker, R.W. (Eds.), The Eastern Pacific Ocean and Hawaii. Geol. Soc. Am., Geol. of North America Ser., N:21-72.

Bader, R.G., Gerard, R.D., et al., 1970. Init. Repts. DSDP, 4: Washington (U.S. Govt. Printing Office).

Benjamin, M., Johnson, N.M., and Naeser, C.W., 1987. Recent rapid uplift in the Bolivian Andes: evidence from fission-track dating. Geology, 15:680-683.

Berger, W.H., Leckie, R.M., Janecek, T.R., Stax, R., and Takayama, T., 1993. Neogene carbonate sedimentation on Ontong Java Plateau: highlights and open questions. In Berger, W.H., Kroenke, L.W., Mayer, L.A., et al., Proc. ODP, Sci. Results, 130: College Station, TX (Ocean Drilling Program), 711-744.

Berggren, W.A., Kent, D.V., Swisher, C.C., III, and Aubry, M.-P., 1995. A revised Cenozoic geochronology and chronostratigraphy. In Berggren, W.A., Kent, D.V., Aubry, M.-P., and Hardenbol, J. (Eds.), Geochronology, Time Scales and Global Stratigraphic Correlation. Spec. Publ.Soc. Econ. Paleontol. Mineral.. 54:129-212.

Berggren, W.A., Kent, D.V., and van Couvering, J., 1985. The Neogene: Part 2. Neogene geochronology and chronostratigraphy. In Snelling, N.J. (Ed.), The Chronology of the Geological Record. Geol. Soc. London Mem., 10:211-260.

Bowin, C., 1976. Caribbean gravity field and plate tectonics. Spec. Pap.Geol. Soc. Am., 169.

Bralower, T.J., Zachos, J.C., Thomas, E., Parrow, M., Paull, C.K., Kelly, D.C., Premoli Silva, I., Sliter, W.V., and Lohmann, K.C., 1995. Late Paleocene to Eocene paleoceanography of the equatorial Pacific Ocean: stable isotopes recorded at Ocean Drilling Program Site 865, Allison Guyot. Paleoceanography, 10:841-865.

Cadet, J.-P., and Fujioka, K., 1980. Neogene volcanic ashes and explosive volcanism: Japan Trench transect, Leg 57, Deep Sea Drilling Project. In von Huene, R., Nasu, N., et al., Init. Repts. DSDP, 56, 57 (Pt. 2): Washington (U.S. Govt. Printing Office), 1027-1041.

Cadet, J.-P., Thisse, Y., Pouclet, A., Bardintzeff, J.M., and Stephan, J.F., 1982a. Tephra from Deep Sea Drilling Project Leg 66: Middle American Trench Transect (Southern Mexico). In Watkins, J.S., Moore, J.C., et al., Init. Repts. DSDP, 66: Washington (U.S. Govt. Printing Office), 687698 .
Cadet, J.-P., Pouclet, A., Thisse, Y., Bardintzeff, J.M., and Azéma, J., 1982b. Middle America Neogene explosive volcanism and ash layers: evidence from the Middle America trench transect, Deep Sea Drilling Project Leg 167. In Aubouin, J., von Huene, R., et al., Init. Repts. DSDP, 67: Washington (U.S. Govt. Printing Office), 475-491.

Cande, S.C., and Kent, D.V., 1995. Revised calibration of the geomagnetic polarity timescale for the Late Cretaceous and Cenozoic. J. Geophys. Res., 100:6093-6095.

Canudo, J.I., Keller, G.. Molina, E., and Ortiz, N., 1995. Planktic foraminiferal turnover and $\delta^{13} \mathrm{C}$ isotopes across the Paleocene-Eocene transition at Caravaca and Zumaya Spain. Palaeogeogr., Palaeoclimatol., Palaeoecol., 114:75-100.

Carey, S., and Sigurdsson, H., 1989. The intensity of plinian eruptions. Bull. Volcanol. 51: 28-40.

Case, J.E., Shagam, R., and Giegengack, R.F., 1990. The geology of the northern Andes: an overview. In Dengo, G., and Case, J.E. (Eds.), The Caribbean Region. Geol. Soc. Am., Geol. of North Am. Ser., H:177200.

Chaisson, W.P., and Leckie, R.M., 1993. High-resolution Neogene planktonic foraminifer biostratigraphy of Site 806, Ontong Java Plateau (western equatorial Pacific). In Berger, W.H., Kroenke, L.W., Mayer, L.A., et al., Proc. ODP, Sci. Results, 130: College Station, TX (Ocean Drilling Program), $137-178$.

Coates, A.G., Jackson, J.B.C., Collins, L.S., Cronin, T.M., Dowsett, H.J., Bybell, L.M., Jung, P., and Obando, J.A., 1992. Closure of the Isthmus of Panama: the near-shore marine record of Costa Rica and western Panama. Geol. Soc. Am. Bull., 104:814-828.

Cofer-Shabica, N.B., 1987. The late Pleistocene deep water history of the Venezuela Basin in the eastern Caribbean Sea [M.S. thesis]. Univ. Miami, Coral Gables, FL.

Curry, W.B., Shackleton, N.J., Richter, C., et al., 1995. Proc. ODP, Init. Repts., 154: College Station, TX (Ocean Drilling Program).

D'Hondt, S., Herbert, T., King, J., and Gibson, C., in press. Planktic foraminifera, asteroids, and marine production: death and recovery at the Cretaceous/Tertiary boundary. In Ryder, G.T., Fastovsky, D.E., and Gartner, S. (Eds.), New Developments Regarding the K/T Event and Other Catastrophes in Earth History. Spec. Pap.-Geol. Soc. Am., 307.

Diebold, J.B., Driscoll, N., Abrams, L., Buhl, P., Donnelly, T., Laine, E., and Leroy, S., 1995a. A regional geophysical survey of the Venezuelan Basin and Beata Ridge: implications for the interpretations of stratigraphy and tectonics. Eos, 76:614.

Diebold, J.B., Driscoll, N.W., Abrams, L., Buhl, P., Donnelly, T.W., Laine, E.P., and Leroy, S., 1995b. Tectonic model for the origin and evolution of the rough/smooth basement in the Venezuelan Basin. Eos, 76:615.

Donnelly, T.W., Beets, D., Carr, M.J., Jackson, T., Klaver, G., Lewis, J., R. Maury, R., Schellenkens, H., Smith, A.L., Wadge, G., and Westercamp, D., 1990. History and tectonic setting of Caribbean magmatism. In Dengo, G., and Case, J.E. (Eds.), The Caribbean Region. Geol. Soc. Am.,Geol. of North Am. Ser., H:339-374.

Droxler, A.W., and Burke, K., 1995. Cenozoic gateway opening and closing in the Caribbean: control on interoceanic and interhemispheric exchange of water masses between the Atlantic and Pacific Oceans. Eos, 76 (Suppl.):53. (Abstract)

Droxler, A.W., Cunningham, A., Hine, A.C., Hallock, P., Duncan, D., Rosencrantz, E., Buffler, R., and Robinson, E., 1992. Late middle(?) Miocene segmentation of an Eocene-early Miocene carbonate megabank on the northern Nicaragua Rise tied to the tectonic activity at the North America/Caribbean plate boundary zone. Eos, 73, Suppl. 43:299. (Abstract)

Droxler, A.W., Morse, J.W., Glaser, K.S., Haddad, G.A., and Baker, P.A., 1991. Surface sediment carbonate mineralogy and water column chemistry: Nicaragua Rise versus the Bahamas. Mar. Geol., 100:277-289.

Duncan, R.A., and Hargraves, R.B., 1984. Plate tectonic evolution of the Caribbean region in the mantle reference frame. In Bonini, W.E., Hargraves, R.B., and Shagam, R. (Eds.), The Caribbean-South American Plate Boundary and Regional Tectonics. Mem.-Geol. Soc. Am., 162:81-94.

Duncan, R.A., Sinton, C.W., and Donnelly, T.W., 1994. The Caribbean basalt province: an oceanic LIP. Eos, 75:594.

Duque-Caro, H., 1990. Neogene stratigraphy, paleoceanography and paleobiogeography in northwest South America and the evolution of the Panama Seaway. Palaeogeogr., Palaeoclimatol., Palaeoecol., 77:203-234.

Edgar, N.T., Saunders, J.B., et al., 1973. Init. Repts. DSDP, 15: Washington (U.S. Government Printing Office). 
Ewing, J., Talwani, M., and Ewing, M., 1968. Sediments of the Caribbean. Proc. Int. Conf. Trop. Oceanogr., Univ. of Miami, 5:88-102.

Farrell, J.W., Raffi, I., Janecek, T.R., Murray, D.W., Levitan, M., Dadey, K.A., Emeis, K-C., Lyle, M., Flores, J-A., and Hovan, S., 1995. Late Neogene sedimentation patterns in the eastern equatorial Pacific Ocean. In Pisias, N.G., Mayer, L.A., Janecek, T.R., Palmer-Julson, A., and van Andel, T.H. (Eds.), Proc. ODP, Sci. Results, 138: College Station, TX (Ocean Drilling Program), 717-756.

Gealey, W.K. 1980. Ophiolite obduction mechanism. In Ophiolites: Proceedings of the International Ophiolite Symposium: Nicosia (Cyprus Geol. Surv. Dept.), 228-243.

Glaser, K.S., and Droxler, A.W., 1993. Controls and development of late Quaternary periplatform carbonate stratigraphy in Walton Basin (northeastern Nicaragua Rise, Caribbean Sea). Paleoceanography, 8: 243-274.

Haddad, G.A., 1994. Calcium carbonate dissolution patterns at intermediate water depths of the tropical oceans. [Ph.D. dissert.], Rice Univ., Houston.

Hall, S.A., and Yeung, T., 1980. A study of magnetic anomalies in the Yucatan Basin. Trans. 11th Carib. Geol. Conf., 35:1-13.

Haq, B.U., Hardenbol, J., and Vail, P.R., 1987. Chronology of fluctuating sea levels since the Triassic. Science, 235:1156-1167.

Hildebrand, A.R., and Boynton, W.V., 1990. Proximal Cretaceous-Tertiary boundary impact deposits in the Caribbean. Science, 248:843-847.

Huber, B.T., Hodell, D.A., and Hamilton, C.P., 1995. Mid- to Late Cretaceous climate of the southern high latitudes: stable isotopic evidence for minimal equator-to-pole thermal gradients. Geol. Soc. Am. Bull., 107:1164-1191.

Keigwin, L., 1982a. Isotopic paleoceanography of the Caribbean and East Pacific: role of Panama Uplift in late Neogene time. Science, 217:350353.

Keigwin, L.D., Jr., 1982b. Neogene planktonic foraminifers from Deep Sea Drilling Project Sites 502 and 503. In Prell, W.L., Gardner, J.V., et al., Init. Repts. DSDP, 68: Washington (U.S. Govt. Printing Office), 269288.

Keller, G., Zenker, C.E., and Stone, S.M., 1989. Late Neogene history of the Pacific-Caribbean gateway. J. South Am. Earth Sci., 2:73-108.

Kelly, D.C., Bralower, T.J., Zachos, J.C., Premoli Silva, I., and Thomas, E., 1996. Rapid diversification of planktonic foraminifera in the tropical Pacific (ODP Site 865) during the late Paleocene thermal maximum. Geology, 24:423-426.

Kennett, J.P., McBirney, A.R., and Thunnell, R.C., 1977. Episodes of Cenozoic volcanism in the Circum-Pacific region. J. Volcanol. Geotherm. Res., 2:145-163.

Kennett, J.P., and Srinivasan, M.S., 1983. Neogene Planktonic Foraminifera: A Phylogenetic Atlas: Stroudsburg, PA (Hutchinson Ross).

Kennett, J.P., and Stott, L.D., 1991. Abrupt deep-sea warming, paleoceanographic changes and benthic extinctions at the end of the Palaeocene. Nature, 353:225-229.

Kennett, J.P., and Thunnell, R.C., 1975. Global increase in Quaternary explosive volcanism. Science, 187:497-503.

Kroenke, L.W., Berger, W.H., Janecek, T.R., et al., 1991. Proc. ODP, Init. Repts., 130: College Station, TX (Ocean Drilling Program).

Lewis, J.F., and Draper, G., 1990. Geology and tectonic evolution of the northern Caribbean margin. In Dengo, G., and Case, J.E. (Eds.), The Caribbean Region. Geol. Soc. Am., Geol. of North Am. Ser., H:77-140.

Lyle, M., Dadey, K.A., and Farrell, J.W., 1995. The late Miocene (11-8 Ma) eastern Pacific carbonate crash: evidence for reorganization of deepwater circulation by the closure of the Panama Gateway. In Pisias, N.G., Mayer, L.A., Janecek, T.R., Palmer-Julson, A., and van Andel, T.H. (Eds.), Proc. ODP, Sci. Results, 138: College Station, TX (Ocean Drilling Program), 821-838.

Mahoney, J.J., 1987. An isotopic survey of Pacific oceanic plateaus: implications for their nature and origin. In Keating, B.H., Fryer, P., Batiza, R., and Boehlert, G.W. (Eds.), Seamounts, Islands, and Atolls. Geophys. Monogr., Am. Geophys. Union, 43:207-220.

Mahoney, J.J., Storey, M., Duncan, R.A., Spencer, K.J., and Pringle, M. 1993. Geochemistry and geochronology of Leg 130 basement lavas: nature and origin of the Ontong Java Plateau. In Berger, W.H., Kroenke, L.W., Mayer, L.A., et al., Proc. ODP, Sci. Results, 130: College Station, TX (Ocean Drilling Program), 3-22.

Mayer, L.A., Theyer, F., Thomas, E., et al., 1985. Init. Repts. DSDP, 85: Washington (U.S. Govt. Printing Office).

Miller, K.G., Wright, J.D., and Fairbanks, R.G., 1991. Unlocking the Ice House: Oligocene-Miocene oxygen isotopes, eustasy, and margin erosion. J. Geophys. Res., 96:6829-6848.
Morris, E.L., Tanner, I., Meyerhoff, H.A., and Meyerhoff, A.A., 1990. Tectonic evolution of the Caribbean region: alternative hypothesis. In Dengo, G., and Case, J.E. (Eds.), The Caribbean Region. Geol. Soc. Am., Geol. of North Am. Ser., H:433-457.

Pak, D.K., and Miller, K.G., 1992. Paleocene to Eocene benthic foraminiferal isotopes and assemblages: implications for deepwater circulation. Paleoceanography, 7:405-422.

Pardo, G., 1975: Geology of Cuba. In Nairn, A.E.M., and Stehli F.G. (Eds.), The Ocean Basins and Margins (Vol, 3): The Gulf of Mexico and the Caribbean: New York (Plenum Press), 553-616.

Perfit, M.R., and Heezen, B.C., 1978. The geology and evolution of the Cayman Trench. Geol. Soc. Amer. Bull., 89:1155-1174.

Peterson, L.C., Murray, D.W., Ehrmann, W.U., and Hempel, P., 1992. Cenozoic carbonate accumulation and compensation depth changes in the Indian Ocean. In Duncan, R.A., Rea, D.K., Kidd, R.B., von Rad, U., and Weissel, J.K. (Eds.), Synthesis of Results from Scientific Drilling in the Indian Ocean. Geophys. Monogr., Am. Geophys. Union, 70:311-333.

Pilkington, M., Hildebrand, A.R., and Ortiz-Aleman, C., 1994. Gravity and magnetic field modeling and structure of the Chicxulub crater, Mexico. $J$. Geophys. Res.,99:13,147-13,162.

Pindell, J.L., 1993. Regional synopsis of Gulf of Mexico and Caribbean evolution. GCSSEPM Found. 13th Ann. Res. Conf. Proc., 251-274.

Pindell, J.L., and Barrett, S.F., 1990. Geologic evolution of the Caribbean region: a plate-tectonic perspective. In Dengo, G., and Case, J.E. (Eds.), The Caribbean Region. Geol. Soc. Am., Geol. North. Am. Ser., H:405432.

Pisias, N.G., Mayer, L.A., and Mix, A.C., 1995. Paleoceanography of the eastern equatorial Pacific during the Neogene: synthesis of Leg 138 drilling results. In Pisias, N.G., Mayer, L.A., Janecek, T.R., Palmer-Julson, A., and van Andel, T.H. (Eds.), Proc. ODP, Sci. Results, 138: College Station, TX (Ocean Drilling Program), 5-21.

Prell, W.L., 1982. Oxygen and carbon isotope stratigraphy for the Quaternary of Hole 502B: evidence for two modes of isotopic variability. In Prell, W.L., Gardner, J.V., et al., Init. Repts. DSDP, 68: Washington (U.S. Govt. Printing Office), $455-464$

Pyle, D.M., 1989. The thickness, volume and grain size of tephra fall deposits. Bull. Volcanol., 51:1-15.

Rea, D.K., Zachos, J.C., Owen, R.M., and Gingerich, P.D., 1990. Global change at the Paleocene-Eocene boundary: climatic and evolutionary consequences of tectonic events. Palaeogeogr., Palaeoclimatol., Palaeoecol., 79:117-128.

Reid, R.P., Carey, S.N., and Ross, D.R., 1996. Late Quaternary sedimentation in the Lesser Antilles Island Arc. Geol. Soc. Am. Bull., 108:78-100.

Reynolds, J.H., 1980. Late Tertiary volcanic stratigraphy of northern Central America. Bull. Volcanol., 43:601-607.

Rosencrantz, E., 1990. Structure and tectonics of the Yucatan Basin (Caribbean Sea) as determined from seismic reflection studies. Tectonics, 9:1037-1059.

Rosencrantz, E., and Sclater, J.G., 1986. Depth and age in the Cayman Trough. Earth Planet. Sci. Lett., 79:133-134.

Schlager, W., Reijmer, J., and Droxler, A.W., 1994. Highstand shedding of carbonate platforms, J. Sediment. Res., B64:270-281.

Schultz, P.H., and D'Hondt, S., 1995. The Chicxulub impact angle and its consequences. Ann. Mtg.-Geol. Soc. Amer., 27:A349. (Abstract)

Schultz, P.H., and Gault, D.E., 1982. Impact ejecta dynamics in an atmosphere: experimental results and extrapolations. Spec. Pap.-Geol. Soc. Am., 190:153-174.

1990. Prolonged global catastrophes from oblique impacts. Spec. Pap.-Geol. Soc. Am., 247:239-261.

Sigurdsson, H., 1990. Assessment of the atmospheric impact of volcanic eruptions. Sp. Pap.-Geol. Soc. Am., 247:99-110.

Sigurdsson, H., Bonté, P., Turpin, L., Chaussidon, M., Metrich, N., Steinberg, M., Pradel, P., and D'Hondt, S., 1991. Geochemical constraints on source region of Cretaceous/Tertiary impact glasses. Nature, 353:839842.

Sigurdsson, H., Sparks, R.S.J., Carey, S.N., and Huang, T.C., 1980. Volcanogenic sedimentation in the Lesser Antilles arc. J. Geol., 88:523-540.

Stott, L.D., Kennett, J.P., Shackleton, N.J., and Corfield, R.M., 1990. The evolution of Antarctic surface waters during the Paleogene: inferences from the stable isotopic composition of planktonic foraminifers, ODP Leg 113. In Barker, P.F., Kennett, J.P., et al., Proc. ODP, Sci. Results, 113: College Station, TX (Ocean Drilling Program), 849-863.

Thomas, E., 1990. Late Cretaceous-early Eocene mass extinctions in the deep sea. In Sharptin, V.L., and Ward, P.D. (Eds.), Global Catastrophes 
in Earth History: An Interdisciplinary Conference on Impacts, Volcanism, and Mass Mortality. Spec. Pap.-Geol. Soc. Am., 247:481-495. - 1992. Cenozoic deep-sea circulation: evidence from deep-sea benthic foraminifera. In Kennett, J.P., and Warnke, D. (Eds.), The Antarctic Paleoenvironment: A Perspective on Global Change. Am. Geophys. Union, Antarct. Res. Ser., 56:141-165.

Thomas, E., and Shackleton, N.J., 1996. The latest Paleocene benthic foraminiferal extinction and stable isotope anomalies. Spec. Publ.-Geol. Soc. London, 101:401-442.

Tjalsma, R.C., and Lohmann, G.P., 1983. Paleocene-Eocene bathyal and abyssal benthic foraminifera from the Atlantic Ocean. Micropaleontol. Spec. Publ., 4.

van Andel, T.H., Heath, G.R., and Moore, T.C., Jr., 1975. Cenozoic history and paleoceanography of the central equatorial Pacific Ocean: a regional synthesis of Deep Sea Drilling Project data. Mem.-Geol. Soc. Am., 143.

Wadge, G., and Burke, K., 1983. Neogene Caribbean Plate rotation and associated Central American tectonic evolution. Tectonics, 2:633-643.

Wessel, P., and Smith, W.H.F., 1991. Free software helps map and display data. Eos, 72:441, 445-446.

Westbrook, G.K., 1990. Gravity anomaly map of the Caribbean region. In Dengo, G., and Case, J.E. (Eds.), The Caribbean Region. Geol. Soc. Am., Geol. of North Am. Ser., H: back pocket.

Weyl, R., 1980. The Geology of Central America: Berlin (Gebruder Borntraeger).

Wright, J.D., and Miller, K.G., 1992. Miocene stable isotope stratigraphy, Site 747, Kerguelen Plateau. In Wise, S.W., Jr., Schlich, R., et al., Proc.
ODP, Sci. Results, 120: College Station, TX (Ocean Drilling Program), 855-866.

, 1993. Southern Ocean influences on Late Eocene to Miocene deep-water circulation. In Kennett, J.P., and Warnke, D.A. (Eds.), The Antarctic Paleoenvironment: A Perspective on Global Change. Antarct. Res. Ser., 60:1-25.

Wright, J.D., Miller, K.G., and Fairbanks, R.G., 1991. Evolution of modern deepwater circulation: evidence from the late Miocene Southern Ocean. Paleoceanography, 6:275-290.

Zachos, J.C., and Arthur, M.A., 1986. Paleoceanography of the Cretaceous/ Tertiary boundary event: inferences from stable isotopic and other data. Paleoceanography, 1:5-26.

Zachos, J.C., Lohmann, K.C., Walker, J.C.G., and Wise, S.W., Jr., 1993. Abrupt climate change and transient climates during the Paleogene: a marine perspective. J. Geol., 101:191-213.

Zachos, J.C., Rea, D.K., Seto, K., Nomura, R., and Niitsuma, N., 1992. Paleogene and early Neogene deep water paleoceanography of the Indian Ocean as determined from benthic foraminifer stable carbon and oxygen isotopic records. In Duncan, R.A., and Rea, D. (Eds.), Synthesis of Results from Scientific Drilling in the Indian Ocean, Geophys. Monogr. Ser., 70:351-386.

\section{Ms 165IR-108}

